\title{
The nitrogen, carbon and greenhouse gas budget of a grazed, cut and fertilised temperate grassland
}

\author{
Stephanie K. Jones ${ }^{1,2}$, Carole Helfter $^{1}$, Margaret Anderson ${ }^{1}$, Mhairi Coyle ${ }^{1}$, Claire Campbell ${ }^{1}$, Daniela Famulari ${ }^{1}$, \\ Chiara Di Marco ${ }^{1}$, Netty van Dijk ${ }^{1}$, Y. Sim Tang ${ }^{1}$, Cairistiona F. E. Topp ${ }^{2}$, Ralf Kiese ${ }^{3}$, Reimo Kindler ${ }^{4}$, Jan Siemens ${ }^{5}$, \\ Marion Schrumpf ${ }^{6}$, Klaus Kaiser ${ }^{7}$, Eiko Nemitz ${ }^{1}$, Peter E. Levy ${ }^{1}$, Robert M. Rees ${ }^{2}$, Mark A. Sutton ${ }^{1}$, and \\ Ute M. Skiba ${ }^{1}$ \\ ${ }^{1}$ Centre for Ecology and Hydrology, Edinburgh, Bush Estate, Penicuik, Midlothian, EH26 QB, UK \\ ${ }^{2}$ Scotland's Rural College, King's Buildings, West Mains Road, Edinburgh, EH9 3JG, UK \\ ${ }^{3}$ Karlsruhe Institute of Technology, Institute for Meteorology and Climate Research, Atmospheric Environmental \\ Research (IMK-IFU), Kreuzeckbahnstr. 19, 82467 Garmisch-Partenkirchen, Germany \\ ${ }^{4}$ Department of Waste Management and Environmental Research, Technische Universität Berlin, Franklinstr. 29, \\ 10587 Berlin, Germany \\ ${ }^{5}$ Chair of Soil Resources, Institute of Soil Science and Soil Conservation, iFZ Research Centre for BioSystems, Land Use and \\ Nutrition, Justus Liebig University Giessen, Heinrich-Buff-Ring 26-32, 35392 Giessen, Germany \\ ${ }^{6}$ Department for Biogeochemical Processes, Max Plank Institute for Biogeochemistry, Hans-Knöll-Str. 10, \\ 07745 Jena, Germany \\ ${ }^{7}$ Soil Science and Soil Protection, Martin Luther University Halle-Wittenberg, Von-Seckendorff-Platz 3, \\ 06120 Halle (Saale), Germany
}

Correspondence to: Stephanie K. Jones (stephanie.jones@sruc.ac.uk)

Received: 23 May 2016 - Discussion started: 22 June 2016

Revised: 23 February 2017 - Accepted: 24 February 2017 - Published: 24 April 2017

\begin{abstract}
Intensively managed grazed grasslands in temperate climates are globally important environments for the exchange of the greenhouse gases (GHGs) carbon dioxide $\left(\mathrm{CO}_{2}\right)$, nitrous oxide $\left(\mathrm{N}_{2} \mathrm{O}\right)$ and methane $\left(\mathrm{CH}_{4}\right)$. We assessed the $\mathrm{N}$ and $\mathrm{C}$ budget of a mostly grazed and occasionally cut and fertilised grassland in SE Scotland by measuring or modelling all relevant imports and exports to the field as well as changes in soil $\mathrm{C}$ and $\mathrm{N}$ stocks over time. The $\mathrm{N}$ budget was dominated by import from inorganic and organic fertilisers $\left(21.9 \mathrm{~g} \mathrm{~N} \mathrm{~m}^{-2} \mathrm{a}^{-1}\right)$ and losses from leaching $\left(5.3 \mathrm{~g} \mathrm{~N} \mathrm{~m}^{-2} \mathrm{a}^{-1}\right), \mathrm{N}_{2}$ emissions $\left(2.9 \mathrm{~g} \mathrm{~N} \mathrm{~m}^{-2} \mathrm{a}^{-1}\right)$, and $\mathrm{NO}_{x}$ and $\mathrm{NH}_{3}$ volatilisation $\left(3.9 \mathrm{~g} \mathrm{~N} \mathrm{~m}^{-2} \mathrm{a}^{-1}\right)$, while $\mathrm{N}_{2} \mathrm{O}$ emission was only $0.6 \mathrm{~g} \mathrm{~N} \mathrm{~m}^{-2} \mathrm{a}^{-1}$. The efficiency of $\mathrm{N}$ use by animal products (meat and wool) averaged $9.9 \%$ of total $\mathrm{N}$ input over only-grazed years (2004-2010). On average over 9 years (2002-2010), the balance of $\mathrm{N}$ fluxes suggested that $6.0 \pm 5.9 \mathrm{~g} \mathrm{~N} \mathrm{~m}^{-2} \mathrm{a}^{-1}$ (mean \pm confidence interval at $p>0.95$ ) were stored in the soil. The largest component of the $\mathrm{C}$ budget was the net ecosystem exchange of $\mathrm{CO}_{2}$
\end{abstract}

(NEE), at an average uptake rate of $218 \pm 155 \mathrm{~g} \mathrm{C} \mathrm{m}^{-2} \mathrm{a}^{-1}$ over the 9 years. This sink strength was offset by carbon export from the field mainly as grass offtake for silage (48.9 $\mathrm{g} \mathrm{C} \mathrm{m}^{-2} \mathrm{a}^{-1}$ ) and leaching $\left(16.4 \mathrm{~g} \mathrm{C} \mathrm{m}^{-2} \mathrm{a}^{-1}\right)$. The other export terms, $\mathrm{CH}_{4}$ emissions from the soil, manure applications and enteric fermentation, were negligible and only contributed to $0.02-4.2 \%$ of the total C losses. Only a small fraction of $\mathrm{C}$ was incorporated into the body of the grazing animals. Inclusion of these $\mathrm{C}$ losses in the budget resulted in a $\mathrm{C}$ sink strength of $163 \pm 140 \mathrm{~g} \mathrm{C} \mathrm{m}^{-2} \mathrm{a}^{-1}$. By contrast, soil stock measurements taken in May 2004 and May 2011 indicated that the grassland sequestered $\mathrm{N}$ in the $0-60 \mathrm{~cm}$ soil layer at $4.51 \pm 2.64 \mathrm{~g} \mathrm{~N} \mathrm{~m}^{-2} \mathrm{a}^{-1}$ and lost $\mathrm{C}$ at a rate of $29.08 \pm 38.19 \mathrm{~g} \mathrm{C} \mathrm{m}^{-2} \mathrm{a}^{-1}$. Potential reasons for the discrepancy between these estimates are probably an underestimation of $\mathrm{C}$ losses, especially from leaching fluxes as well as from animal respiration. The average greenhouse gas (GHG) balance of the grassland was $-366 \pm 601 \mathrm{~g} \mathrm{CO}_{2}$ eq. $\mathrm{m}^{-2} \mathrm{yr}^{-1}$ and was strongly affected 
by $\mathrm{CH}_{4}$ and $\mathrm{N}_{2} \mathrm{O}$ emissions. The GHG sink strength of the NEE was reduced by $54 \%$ by $\mathrm{CH}_{4}$ and $\mathrm{N}_{2} \mathrm{O}$ emissions. Estimated enteric fermentation from ruminating sheep proved to be an important $\mathrm{CH}_{4}$ source, exceeding the contribution of $\mathrm{N}_{2} \mathrm{O}$ to the GHG budget in some years.

\section{Introduction}

Managed grasslands cover an estimated $26 \%$ of earth's land surface (FAOstat, 2008). The impact of reactive nitrogen $(\mathrm{Nr})$ losses, carbon (C) sequestration and greenhouse gas (GHG) emissions $\left(\mathrm{CO}_{2}, \mathrm{CH}_{4}\right.$ and $\left.\mathrm{N}_{2} \mathrm{O}\right)$ from these grasslands is therefore of global importance and will become even more relevant in the future as increased standards of living in developing countries are expected to result in a rapid growth of livestock farming (Caro et al., 2014). Carbon and N cycles in grasslands are intricately linked and tightly coupled in extensively managed low- $\mathrm{N}$ grasslands, with sinks and sources in equilibrium. Converting such systems to intensively managed $\mathrm{N}$-fertilised grasslands in the short term may increase the soil organic carbon (SOC) pool from decomposed plant litter and root material as well as through rhizodeposition (Rees et al., 2005) until a new equilibrium is reached (Soussana and Lemaire, 2014). In the case of the long-term Broadbalk experiment in the UK, this equilibrium was achieved after 50 years (Powlson et al., 2011). After the conversion to intensive $\mathrm{N}$ management, the tight coupling of the $\mathrm{N}$ and $\mathrm{C}$ cycles becomes disrupted, leading to emissions of $\mathrm{N}_{2} \mathrm{O}$ and $\mathrm{CH}_{4}$ at rates which may outweigh the benefits of $\mathrm{C}$ sequestration; increased $\mathrm{N}$ input will lead to a decrease in the $\mathrm{C} / \mathrm{N}$ ratio of the soil resulting in increased nitrification and denitrification processes and thus $\mathrm{N}_{2} \mathrm{O}$ losses (Mu et al., 2014), while $\mathrm{N}$ fertilisation is a key factor inhibiting $\mathrm{CH}_{4}$ oxidation in soils. Mosier et al. (1991) reported an inhibition of $\mathrm{CH}_{4}$ uptake on grassland by $41 \%$ after the application of $\mathrm{N}$ fertiliser. Several studies indicate that managed grasslands can sequester C (Kim et al., 1992; Jones et al., 2006; Soussana et al., 2004; Ammann et al., 2007) however, uncertainties are high (Janssens et al., 2003). By contrast, Smith (2014) concluded from long-term experiments and chronosequence studies that changes in agronomic management may lead to short-term $\mathrm{C}$ sequestration, but in the long-term, under constant management and environmental conditions, $\mathrm{C}$ stocks are relatively stable. In a grassland ecosystem the $\mathrm{C}$ balance is determined by the net biome exchange (the difference between total $\mathrm{C}$ input and losses). In managed grassland ecosystems, exports through biomass harvesting, the addition of organic manures (from organic fertiliser additions and animal excretion) as well as $\mathrm{CO}_{2}$ and $\mathrm{CH}_{4}$ losses from animal respiration and enteric fermentation can make significant contributions to the $\mathrm{C}$ budget.

Nutrient budgets are a valuable tool to summarise and understand nutrient cycling in agroecoystems and to assess their impact on the environment. As imbalances are not sustainable in the long term, $\mathrm{N}$ and $\mathrm{C}$ budgets can be used as indicators and regulatory policy instruments for nutrient management in order to reduce losses and increase efficiency. So far, different $\mathrm{Nr}$ species have been looked at in separate studies according to their form and impact. Few studies have attempted to calculate $\mathrm{N}$ budgets from managed grasslands (e.g. Chen et al., 2004; Ammann et al., 2009; Kramberger et al., 2015), whereas $C$ budgets have been assessed more often and are available for various ecosystems (e.g. Aubinet et al., 2000; Soussana et al., 2007; Ammann et al., 2007; Rytter et al. 2015). To calculate the total $\mathrm{C}$ and $\mathrm{N}$ budget of an ecosystem all import and export processes have to be assessed by measuring or estimating all imports and exports to an ecosystem. The other method is to measure differences in $\mathrm{N}$ and $\mathrm{C}$ stocks in the soil over time. This approach has the advantage that it requires the measurement of only a single component of the system. However, a large number of samples is needed at an interval of more than 5 years before detectable changes may be statistically significant (Smith, 2004). Moreover this approach does not provide any information about the different processes leading to the final budget.

In this study we assessed the $\mathrm{C}$ and $\mathrm{N}$ budget from an intensively managed grassland in southern Scotland using both approaches. Here we report one of the most detailed analyses of $\mathrm{C}$ and $\mathrm{N}$ fluxes from a grassland ecosystem over 9 years (2002-2010). This study allowed an analysis of the importance of common grassland management practices such as cutting for silage, grazing of cattle and sheep at different stocking densities, $\mathrm{N}$ input by inorganic and organic fertiliser applications, as well as different weather conditions for the N, C and GHG balance. The data provide a unique overview of research undertaken within the three European projects GREENGRASS (Soussana et al., 2007), CarboEurope (Schulze et al., 2009) and NitroEurope (Sutton et al., 2007; Skiba et al., 2009).

\section{Methods}

\subsection{Site description}

The experimental site, Easter Bush, is located in south-east Scotland, $10 \mathrm{~km}$ south of Edinburgh $\left(03^{\circ} 02^{\prime} \mathrm{W}, 55^{\circ} 52^{\prime} \mathrm{N}\right.$; 190 ma.s.1.), with a mean annual rainfall of $947 \pm 234 \mathrm{~mm}$ and a mean annual temperature of $9.0 \pm 0.4^{\circ} \mathrm{C}(2002-2010)$. The field $(5.424 \mathrm{ha})$ has been under permanent grassland management for more than 20 years before the start of the experiment with a species composition of $>99 \%$ perennial ryegrass (Lolium perenne) and $<0.5 \%$ white clover (Trifolium repens). The soil type is an imperfectly drained Macmerry soil series, Rowanhill soil association (Eutric Cambisol), with a pH of 5.1 (in $\mathrm{H}_{2} \mathrm{O}$ ) and a clay fraction of $20-26 \%$. The ground water table was assumed to be at $0.85 \mathrm{~m}$ depth on 


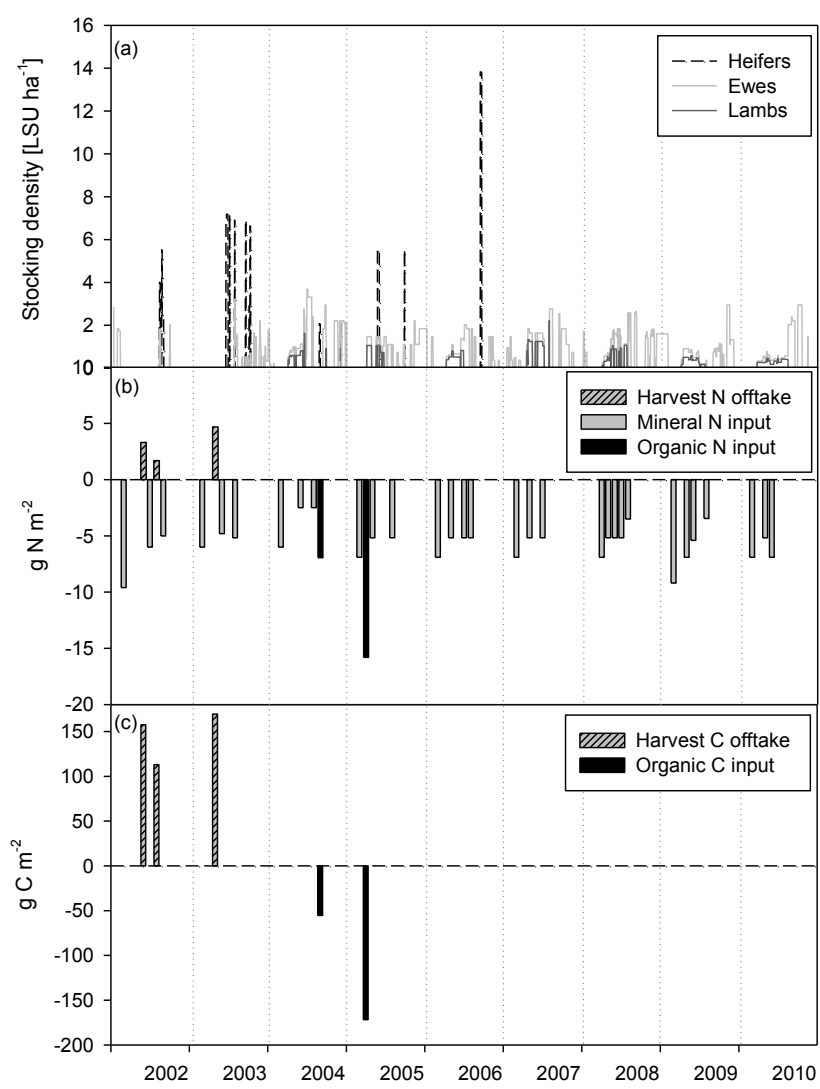

Figure 1. Stocking density (a) and nitrogen (b) and carbon (c) input and export from inorganic and organic fertiliser and harvest from 2002 to 2010. LSU stands for livestock unit, where 1 livestock unit has a standard live weight of $600 \mathrm{~kg} \mathrm{head}^{-1}$.

average, and the main rooting zone extends down to $0.31 \mathrm{~m}$ below the soil surface.

\subsection{Grassland management}

The grassland was grazed rotationally throughout the experimental period by heifers in calf, ewes and lambs at different stocking densities (Table 1 and Fig. 1a). Livestock units used for heifers, ewes and lambs were 0.75, 0.10 and 0.04, respectively (1 livestock unit has a standard live weight of $\left.600 \mathrm{~kg} \mathrm{head}^{-1} ; \mathrm{SAC}, 1995\right)$. Lambs were present on the field from April to September only. The grass was cut for silage only in the first 2 years, on the 1 June and 8 August 2002 and on the 29 May 2003. Ammonium nitrate fertiliser was applied to the field three to four times per year, usually between March and July (56 kg N ha ${ }^{-1}$ application $^{-1}$ on average). In 2008 an additional fifth mineral $\mathrm{N}$ application was added, using urea instead of ammonium nitrate fertiliser. Organic manure was applied on 28 September 2004 and 27 March 2005 as cattle slurry, using a vacuum slurry spreader (Tables 3 and 4 and Fig. $1 b$ and c).

\subsection{Annual budget calculations}

We assessed the $\mathrm{N}$ and $\mathrm{C}$ budget by measuring or estimating the import and export of all relevant fluxes to and from the grassland field on an annual basis. Throughout the paper all fluxes are presented following the sign convention used in micrometeorology; fluxes from the ecosystem to the atmosphere are positive (exported from the field), while negative values indicate fluxes from the atmosphere to the ecosystem (imported to the field). We set the system boundary for inputs and exports of $\mathrm{N}$ and $\mathrm{C}$ by the field perimeters. The balance of all imports and exports results in the observed changes in $\mathrm{N}$ and $\mathrm{C}$ on this field over time.

The change in the $\mathrm{N}$ balance $(\Delta \mathrm{N})$ over time $(\Delta t)$ of our grassland ecosystem can be written as

$$
\begin{aligned}
\Delta \mathrm{N} / \Delta t & =\mathrm{FN}_{\text {org fert. }}+\mathrm{FN}_{\text {synt fert. }}+\mathrm{FN}_{\text {feed }} \\
& +\mathrm{FN}_{\mathrm{N}_{2} \text { (biol. fixation) }}+\mathrm{FN}_{\text {dep. }}+\mathrm{FN}_{\text {harvest }} \\
& +\mathrm{FN}_{\text {animal }}+\mathrm{FN}_{\text {leaching }} \\
& +\mathrm{FN}_{\mathrm{NH}_{3}, \mathrm{NO}_{x} \text { (fert., manure, animal) }} \\
& +\left(\mathrm{FN}_{\mathrm{NO}_{x} \text { (soil) }}+\mathrm{FN}_{\mathrm{N}_{2} \mathrm{O}}+\mathrm{FN}_{\mathrm{N}_{2} \text { (denitr.) }}\right.
\end{aligned}
$$

$\mathrm{N}$ imports include the addition of $\mathrm{N}$ from organic and inorganic fertiliser $\left(\mathrm{FN}_{\text {org fert. }}+\mathrm{FN}_{\text {synt fert. }}\right)$, cake concentrate fed to ewes during lactation $\left(\mathrm{FN}_{\text {feed }}\right)$, the fixation of $\mathrm{N}_{2}$ through biological fixation $\left(\mathrm{FN}_{\mathrm{N}_{2} \text { (biol. fixation) }}\right.$ ), and the deposition of $\mathrm{NH}_{3}, \mathrm{HNO}_{3}, \mathrm{NH}_{4}^{+}, \mathrm{NO}_{3}^{-}$from dry and $\mathrm{NH}_{4}^{+}$ and $\mathrm{NO}_{3}^{-}$from wet deposition (summarised as $\mathrm{FN}_{\text {dep. }}$.). Exports include the $\mathrm{N}$ lost from plant biomass at cuts for silage ( $\left.\mathrm{FN}_{\text {harvest }}\right)$ the offtake of $\mathrm{N}$ in meat (including bones) and wool from animals $\left(\mathrm{FN}_{\text {animal }}\right)$, the loss of organic and inorganic dissolved $\mathrm{N}$ through leaching $\left(\mathrm{FN}_{\text {leaching }}\right)$, the $\mathrm{NH}_{3}$ and $\mathrm{NO}_{x}$ emissions from the volatilisation of inorganic and organic fertiliser spreading as well as from animal excre-

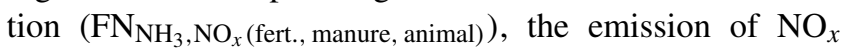

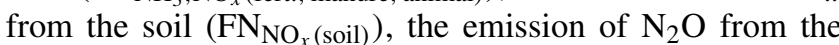
soil $\left(\mathrm{FN}_{\mathrm{N}_{2} \mathrm{O}}\right)$, and the loss of $\mathrm{N}_{2}$ from total denitrification

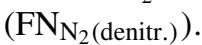

The change in the $\mathrm{C}$ balance $(\Delta \mathrm{C})$ over time equals the net biome production (NBP) and can be written for our site as

$$
\begin{aligned}
\Delta \mathrm{C} / \Delta t & =\mathrm{NBP}=\mathrm{FC}_{\mathrm{CO}_{2}}+\mathrm{FC}_{\text {org fert }}+\mathrm{FC}_{\text {animal }} \\
& +\mathrm{FC}_{\mathrm{CH}_{4}}+\mathrm{FC}_{\text {leaching }}+\mathrm{FC}_{\text {harvest }} .
\end{aligned}
$$

$\mathrm{FC}_{\mathrm{CO}_{2}}$ represents the net ecosystem exchange (NEE) of $\mathrm{CO}_{2}$, and $\mathrm{FC}_{\text {org fert }}$ is the $\mathrm{C}$ input through manure application. Carbon input from animal excretion was not included in the budget as it was assumed to be recycled $\mathrm{C}$ from plant and soil uptake. $\mathrm{FC}_{\text {animal }}$ includes the $\mathrm{C}$ offtake through animal weight increase and wool production. As grazing cows were heifers in calf and ewes' milk was consumed by their lambs, there was no $\mathrm{C}$ offtake through milk to be considered. Methane emissions from enteric fermentation by ruminants, animal excretion and manure application as well as $\mathrm{CH}_{4}$ fluxes from the soil are included in $\mathrm{FC}_{\mathrm{CH}_{4}}$. $\mathrm{FC}_{\text {leaching }}$ 
Table 1. Average annual stocking rates $\left(\mathrm{LSU}^{*} \mathrm{ha}^{-1} \mathrm{a}^{-1}\right)$.

\begin{tabular}{lrrrrrrrrr}
\hline & 2002 & 2003 & 2004 & 2005 & 2006 & 2007 & 2008 & 2009 & 2010 \\
\hline Heifers & 0.12 & 0.38 & 0.05 & 0.15 & 0.27 & 0 & 0 & 0 & 0 \\
Ewes & 0.14 & 0.16 & 0.82 & 0.56 & 0.51 & 0.68 & 0.68 & 0.61 & 0.53 \\
Lambs & 0 & 0 & 0.12 & 0.12 & 0.12 & 0.23 & 0.14 & 0.11 & 0.12 \\
All animals & 0.27 & 0.54 & 0.99 & 0.83 & 0.90 & 0.91 & 0.83 & 0.72 & 0.65 \\
\hline
\end{tabular}

* LSU stands for livestock units; 1 LSU has a standard live weight of $600 \mathrm{~kg} \mathrm{head}^{-1}$ (Scottish Agricultural College, 1995).

is the $\mathrm{C}$ lost through dissolved organic and inorganic $\mathrm{C}$ and dissolved $\mathrm{CH}_{4}$ leaching, and $\mathrm{FC}_{\text {harvest }}$ represents the $\mathrm{C}$ lost from the system through plant biomass export from harvests (cut for silage). Carbon emissions from farm operations (i.e. tractor emissions) or off-farm emissions (i.e. fertiliser manufacture) are not included in the $\mathrm{C}$ budget.

Details of methods to quantify each $\mathrm{N}$ and $\mathrm{C}$ budget component, as listed in Eqs. (1) and (2), are described under Sect. 2.4 to 2.17 and in the Supplement. Some budget components were measured throughout the 9 years presented, while others were only measured in some years or not at all. Missing data were derived from the literature, models or averages from available data from other years.

The annual net GHG exchange (NGHGE) was calculated from annual $\mathrm{NEE}\left(\mathrm{FC}_{\mathrm{CO}_{2}}\right), \mathrm{CH}_{4}\left(\mathrm{FC}_{\mathrm{CH}_{4}}\right)$ and $\mathrm{N}_{2} \mathrm{O}\left(\mathrm{FN}_{\mathrm{N}_{2} \mathrm{O}}\right)$ fluxes using global warming potentials (GWPs) at the 100year time horizon ( 1 for $\mathrm{CO}_{2}, 298$ for $\mathrm{N}_{2} \mathrm{O}$ and 25 for $\mathrm{CH}_{4}$, IPCC, 2013):

$\mathrm{NGHGE}=\left(\mathrm{FC}_{\mathrm{CO}_{2}}\right)+\mathrm{FC}_{\mathrm{CH}_{4}} \times k_{\mathrm{CH}_{4}}+\mathrm{FN}_{\mathrm{N}_{2} \mathrm{O}} \times k_{\mathrm{N}_{2} \mathrm{O}}$,

where

$k_{\mathrm{CH}_{4}}=9.09$, since $1 \mathrm{kgCH}_{4}-\mathrm{C}$ corresponds to

$$
9.09 \mathrm{~kg} \mathrm{CO}_{2}-\mathrm{C} \text {, }
$$

$k_{\mathrm{N}_{2} \mathrm{O}}=127$, since $1 \mathrm{kgN}_{2} \mathrm{O}-\mathrm{N}$ corresponds to

$$
127 \mathrm{~kg} \mathrm{CO}_{2}-\mathrm{C} \text {. }
$$

In addition the net annual greenhouse gas balance (NGHGB) was calculated by including the loss of $\mathrm{C}$ through animal meat and wool production, harvest offtake, $\mathrm{C}$ leaching, and input by organic fertiliser application:

$$
\begin{aligned}
\mathrm{NGHGB} & =\mathrm{NGHGE}+\mathrm{FC}_{\text {org fert }}+\mathrm{FC}_{\text {animal }} \\
& +\mathrm{FC}_{\text {leach }}+\mathrm{FC}_{\text {harvest }} .
\end{aligned}
$$

\subsection{Nitrogen and carbon import by fertiliser and manure $\left(\mathbf{F N}_{\text {synt fert }}+\mathbf{F N}_{\text {org fert. }}+\mathbf{F C}_{\text {org fert }}\right)$}

Mineral fertiliser was applied by a spreader as either ammonium nitrate or urea. Six-month-old cattle slurry was spread by a vacuum slurry tanker. Data of application rates and $\mathrm{N}$ content were obtained from the farmer. Three samples from the slurry tank were taken at each application and analysed for ammoniacal nitrogen $\left(\mathrm{NH}_{3}\right.$ and $\left.\mathrm{NH}_{4}^{+}\right)$, dry-matter content, total $\mathrm{N}$, total $\mathrm{C}, \mathrm{pH}$ and nitrate. The total $\mathrm{N}$ and $\mathrm{C}$ import to the field by the slurry was calculated by the volume of the slurry applied and the $\mathrm{N}$ and $\mathrm{C}$ analyses of the slurry.

\section{5 $\mathrm{N}$ import through standard cake concentrate $\left(\mathbf{F N}_{\text {feed }}\right)$}

Ewes were given standard cake concentrate "Davidsons super ewe nuts" during lactation, which contained $20 \%$ protein. They were given $1 \mathrm{~kg}$ of this additional feed per day for 7 weeks in spring. This resulted in an extra $\mathrm{N}$ intake of $0.032 \mathrm{~kg} \mathrm{~N}$ per ewe per day (assuming an $\mathrm{N}$ content of $16 \%$ of protein; IPCC, 2006a).

\subsection{Nitrogen and carbon export by harvest $\left(\mathrm{FN}_{\text {harvest }}+\right.$ FC harvest)}

The farmer estimated a forage harvest of $15 \mathrm{t}$ fresh weight (FW) per hectare at the first cut and $10 \mathrm{tFW} \mathrm{ha}^{-1}$ at the second cut of a year, based on the plant height at the field at the time of cutting and information from harvested plot experiments. As there were two cuts in 2002 and one cut in 2003 the estimated harvest was $25 \mathrm{tFW} \mathrm{ha}^{-1} \mathrm{a}^{-1}$ for 2002 and $15 \mathrm{tFW} \mathrm{ha}^{-1} \mathrm{a}^{-1}$ for 2003. A subsample of harvested vegetation was collected and dried at $80^{\circ} \mathrm{C}$ for plant $\mathrm{N}$ and $\mathrm{C}$ analysis using a Carbo-Erba/400 automated $\mathrm{N}$ and $\mathrm{C}$ analyser.

\subsection{Nitrogen and carbon export by meat and wool $\left(\mathrm{FN}_{\text {animal }}+\mathrm{FC}_{\text {animal }}\right)$}

It was estimated by the farmer that heifers increased in weight by $0.8 \mathrm{~kg}$ per day (starting weight of $450 \mathrm{~kg}$ ). The ewe weight was assumed to be constant $(60 \mathrm{~kg})$. They were fed extra protein (standard cake concentrate) to reduce weight loss during lactation, whereas lambs were brought to the field at a weight of $5 \mathrm{~kg}$ and removed when they reached a weight of $45 \mathrm{~kg}$. All animals were weighed before they came onto the field at the beginning of the season and again at the end of the season. The total meat export, which includes bones, was calculated from the daily weight increase in heifers and lambs multiplied by the animal number per day. To calculate the $\mathrm{N}$ and $\mathrm{C}$ export from meat, we assumed an $\mathrm{N}$ content of 
meat of $3.5 \%$ and a C content of meat of $21 \%$ (Flindt, 2002), an $\mathrm{N}$ content of bones of $7 \%$ and a $\mathrm{C}$ content of bones of $20 \%$ (Marchand, 1842), assuming a total bone content of $20 \%$ for sheep (Lambe et al., 2007) and $14 \%$ for heifers (Navajas et al., 2010) . Ewes were sheared annually in June, yielding an estimated $2.5 \mathrm{~kg}$ of wool per sheep. Wool $\mathrm{N}$ and $\mathrm{C}$ export was calculated from wool production multiplied by the average sheep number in June, assuming an $\mathrm{N}$ and $\mathrm{C}$ content of wool of 16.5 and $50 \%$, respectively (Roche, 1995).

\subsection{Nitrogen and carbon leaching (FN leaching $\left.+\mathrm{FC}_{\text {leaching }}\right)$}

Two sets of 10 glass suction cups (pore size $<1 \mu \mathrm{m}$, ecoTech, Bonn, Germany) for soil water and 4 Teflon suction cups (ecoTech, Bonn, Germany) for soil gas collection were installed in August 2006. One set was located on a slope, another in a hollow. For the budget calculations we only used results from the slope location as the hollow location was frequently water logged. Suction cups were installed horizontally from a soil pit beneath the A horizon $(30 \mathrm{~cm}$ depth) and at $90 \mathrm{~cm}$ depth and connected to $2 \mathrm{~L}$ glass bottles in an insulated aluminium box placed into the soil pit. Samples were collected every 2-3 weeks. For further details and description of dissolved organic and inorganic $\mathrm{C}$ (DIC, DOC) and dissolved $\mathrm{CH}_{4}$ analysis see Kindler et al. (2011). Dissolved inorganic and organic N (DIN, DON) and total N (TN) concentrations in leachate water were analysed by colorimetric analysis $\left(\mathrm{San}^{++}\right.$, automated wet chemistry analyser continuous-flow analyser (CFA), Skalar, the Netherlands). Leachate $\mathrm{C}$ and $\mathrm{N}$ concentrations were measured from $1 \mathrm{Oc}-$ tober 2006 to 30 March 2008. Dissolved C and N were calculated by multiplying concentrations of DIC, DOC and dissolved $\mathrm{CH}_{4}$ or DIN and DON, respectively, with leachate volume. The latter was derived from a soil water model based on balancing daily precipitation and evaporation considering the water-holding capacity of the soil (Kindler et al., 2011). To calculate the annual leaching flux for 2007, data were gap filled using daily average values for missing data. For the remaining years $\mathrm{N}$ was simulated using the LandscapeDNDC model (Haas et al., 2013), with the model tested and validated with comprehensive measured data. For $\mathrm{C}$ leaching linear regression models describing the relationship between calculated $\mathrm{C}$ leaching fluxes and leachate volume for the measurement period (DOC: $y=0.0186 x-0.0695, R^{2}=0.8663$; DIC: $y=0.021 x-0.0008, R^{2}=0.8056$; and dissolved $\mathrm{CH}_{4}$ : $y=0.0019 x-0.0135, R^{2}=0.7623$ ) were used to extrapolate to the remaining years.

\section{9 $\quad$ deposition $\left(\mathbf{F} \mathbf{N}_{\text {dep }}\right)$}

\subsubsection{Wet $\mathbf{N}$ deposition}

Wet $\mathrm{N}$ deposition was determined from daily samples collected by an automatic precipitation sampler (Eigenbrodt ${ }^{\circledR}$ precipitation collector $181 / \mathrm{KS}$, Königsmoor, Germany) at Auchencorth Moss ( $\left.3^{\circ} 14^{\prime} 35 \mathrm{~W}, 55^{\circ} 47^{\prime} 34 \mathrm{~N}\right), 17 \mathrm{~km}$ southwest of Easter Bush (Skiba et al., 2013; McKenzie et al., 2016). Precipitation samples were analysed for $\mathrm{NO}_{3}^{-}$and $\mathrm{NH}_{4}^{+}$by ion chromatography (Methrom AG, Switzerland). Typical detection limits were $0.5 \mu \mathrm{M}$ for $\mathrm{NH}_{4}^{+}$and $0.4 \mu \mathrm{M}$ for $\mathrm{NO}_{3}^{-}$. Annual inorganic $\mathrm{N}$ deposition at this site was then adjusted to annual rainfall amounts measured at Easter Bush.

\subsubsection{Dry $\mathbf{N}$ deposition}

Cumulative monthly concentrations of gaseous and aerosol $\mathrm{N}$ species $\left(\mathrm{NH}_{3}, \mathrm{HNO}_{3}\right.$, particulate $\mathrm{NH}_{4}^{+}$and $\left.\mathrm{NO}_{3}^{-}\right)$were collected from another field, at about $300 \mathrm{~m}$ distance from our study field, using a DELTA system (DEnuder for Long Term Atmospheric sampling; Sutton et al., 2001). N dry-deposition fluxes were calculated using the average flux from four different inferential models, as described in detail by Flechard et al. (2011).

\section{$2.10 \quad \mathrm{~N}_{2} \mathrm{O}$ fluxes $\left(\mathrm{FN}_{\mathrm{N}_{2}} \mathrm{O}\right)$}

From June 2002 to July $2003 \mathrm{~N}_{2} \mathrm{O}$ fluxes were measured continuously by eddy covariance (EC) using an ultrasonic anemometer coupled with a tunable diode laser absorption spectrometer (TDL) at a frequency of $10 \mathrm{~Hz}$. Details of the gap-filling method of the $\mathrm{N}_{2} \mathrm{O}-\mathrm{EC}$ data are described in Jones et al. (2011). From August 2006 to November 2010, $\mathrm{N}_{2} \mathrm{O}$ fluxes were measured using manual closed static chambers (Clayton et al.,1994; Skiba et al., 2013). Samples were analysed for $\mathrm{N}_{2} \mathrm{O}$ using a Hewlett Packard 5890 series II gas chromatograph (GC) (Agilent Technologies, Stockport, UK), fitted with an electron capture detector (detection limit: $\mathrm{N}_{2} \mathrm{O}<33 \mathrm{ppbV}$ ). Fluxes were measured weekly and more frequently during fertilisation. Cumulative fluxes were calculated by gap filling data for missing days using linear interpolation and summing up all gapfilled data over each calendar year. For the periods where no $\mathrm{N}_{2} \mathrm{O}$ fluxes were measured (January-May 2002, July 2003-March 2004, May 2004-July 2006) fluxes were simulated by LandscapeDNDC (Haas et al., 2013). LandscapeDNDC was tested in detail with available data on plant growth, soil temperature, moisture, inorganic soil $\mathrm{N}$ concentration, $\mathrm{NO}$ and $\mathrm{N}_{2} \mathrm{O}$, which resulted in general good agreement of simulations and measurements. Results except for NO emissions are published in Molina et al. (2016).

\section{$2.11 \mathrm{NO}_{x}$ fluxes $\left(\mathrm{FN}_{\mathrm{NO}_{x}}(\right.$ soil $)$}

$\mathrm{NO}_{x}$ fluxes from the soil were only measured for a short period (June 2009-August 2010). The $\mathrm{NO}_{x}$ fluxes were measured using an autochamber system described in detail by Butterbach-Bahl et al. (1997). Measurements were made four times per day, every $6 \mathrm{~h}$ for an $8 \mathrm{~min}$ period per chamber. We 
used simulated data from LandscapeDNDC for years where no $\mathrm{NO}_{x}$ fluxes were measured.

\section{$2.12 \mathrm{NH}_{3}+\mathrm{NO}_{x}$ volatilisation \\ $\left(\mathrm{FN}_{\mathrm{NH}_{3}, \mathrm{NO}_{x} \text { (fert., manure, animal) }}\right)$}

The fraction of nitrogen that volatilises as $\mathrm{NH}_{3}$ and $\mathrm{NO}_{x}$ from applied synthetic fertiliser or cattle slurry application and animal excretion was estimated to be 10 and $20 \%$ of total $\mathrm{N}$ applied, respectively (IPCC, 2006b). The animal excretion amount was estimated in accordance with the IPCC guidelines (IPCC, 2006a); for details, please see the Supplement.

\section{$2.13 \mathrm{~N}_{2}$ emission by total denitrification $\left(\mathrm{FN}_{\left.\mathrm{N}_{2} \text { (denitr. }\right)}\right)$}

Dinitrogen $\left(\mathrm{N}_{2}\right)$ emissions resulting from total denitrification in the soil was not measured in our experiment. We therefore used the $\mathrm{N}_{2}$ emission rates from LandscapeDNDC simulations.

\subsection{Biological $\mathrm{N}_{2}$ fixation ( $\mathrm{FN}_{\mathrm{N}_{2} \text { (biol. fixation) }}$ )}

The species composition was measured once in 2002 and at monthly intervals in 2003 by the visual estimation method (Braun-Blanquet, 1964), where 50 quadrats of $0.25 \mathrm{~m}^{2}$ were distributed across the field at random. As the legume fraction (Trifolium repens) was smaller than $0.5 \%$ at each measuring point, we assumed the nitrogen fixation through plants to be zero.

\subsection{Exchange of $\mathrm{CO}_{2}\left(\mathrm{FC}_{\mathrm{CO}_{2}}\right)$}

NEE was measured continuously from 1 January 2002 till 31 December 2010 by an eddy covariance system consisting of a fast-response 3-D ultrasonic anemometer (Metek USA1, Metek GmbH, Elsmhorn, Germany) and a fast closedpath $\mathrm{CO}_{2}-\mathrm{H}_{2} \mathrm{O}$ analyser (LI-COR 7000 infrared gas analyser (IRGA), LI-COR, Lincoln, NE, USA). NEE is the arithmetic sum of the gross primary production (GPP) and total ecosystem respiration (TER). Flux partitioning of measured NEE into GPP and TER was calculated by the same online tool used for gap filling (http://www.bgc-jena.mpg.de/ $\sim$ MDIwork/eddyproc/upload.php, Reichstein et al., 2005). In this flux-partitioning approach, daytime TER is obtained by the extrapolation of a nighttime parameterisation of NEE on air temperature and GPP is the difference between ecosystem respiration and NEE. Contrary to unmanaged ecosystem, TER at our site also includes the respiratory loss of $\mathrm{CO}_{2}$ by grazing animals. Net primary production (NPP), which represents the annual plant growth (difference between GPP and autotrophic respiration) was calculated as $50 \%$ of GPP (Amthor, 2000; Zhang et al., 2009).

\subsection{Methane fluxes $\left(\mathrm{FC}_{\mathrm{CH}_{4}}\right)$}

Methane fluxes from the soil were measured with closed static chambers simultaneously with the $\mathrm{N}_{2} \mathrm{O}$ measurements (see Sect. 2.10). The same GC was fitted with a flame injection detector (detection limit: $\mathrm{CH}_{4}<70 \mathrm{ppbV}$ ). The minimal detectable flux was $17 \mathrm{ng} \mathrm{CH}_{4}-\mathrm{C} \mathrm{m}^{-2} \mathrm{~s}^{-1}$. Fluxes were measured weekly and more frequently at fertilisation events. As measured soil $\mathrm{CH}_{4}$ fluxes were close to zero and did not vary significantly between months, we calculated $\mathrm{CH}_{4}$ for months where no $\mathrm{CH}_{4}$ fluxes were measured (January-May 2002, July 2003-March 2004, May 2004-July 2006) as an average monthly cumulative flux from other years.

Methane emissions from grazing animals, i.e. animal excretion and enteric fermentation, were estimated following the IPCC Tier 2 methodology (IPCC, 2006a; Stewart et al., 2009). For details, see the Supplement. Methane emissions from slurry applications were assumed to be small. As no chamber measurements were conducted at the time of slurry spreading, the emissions were estimated as $0.07 \%$ of the slurry applied assuming that emissions were comparable to those in a related study (Jones et al., 2006), where $\mathrm{CH}_{4}$ was measured from chambers after slurry application on a nearby field in 2002 and 2003.

\subsection{VOC}

Fluxes of non-methane volatile organic compounds (VOCs) were not measured. We assumed similar VOC emissions to those reported by Davison et al. (2008) for an intensively managed grassland in Switzerland, where the daily average flux of methanol, acetaldehyde and acetone over 3 days after cutting was $21.1,5.1$ and $2.6 \mathrm{nmol} \mathrm{m}^{-2} \mathrm{~s}^{-1}$, respectively. Based on those values, annual VOC emissions from our field were estimated to be in the order of $0.03 \%$ of the annual $\mathrm{C}$ offtake in harvest and $0.08 \%$ of annual $\mathrm{C}$ offtake by grazing animals. We therefore assumed VOC emissions to be negligible and did not account for them in the $\mathrm{C}$ balance.

\subsection{Soil $N$ and $C$ measurements}

Total $\mathrm{N}$ and C content of the soil were measured in May 2004 and May 2011. One hundred soil cores with an inner diameter of 8.7 (2004) and $8.3 \mathrm{~cm}$ (2009; both corers from Eijkelkamp Agrisearch Equipment BV, Giesbeek, the Netherlands) were collected along a regular grid with a distance of $10 \mathrm{~m}$ between sampling points on both occasions. The soil sampling grid covered the main footprint area of the site, not the entire field. Cores were separated into layers of 0 $5,5-10,10-20,20-30,30-40,40-50$ and 50-60 cm. Coarse stones of a diameter $>4 \mathrm{~mm}$ and roots of a diameter $>1 \mathrm{~mm}$ were removed from the samples prior to drying at $40^{\circ} \mathrm{C}$. Stone and root samples were air-dried separately. Then, soil samples were sieved to $<2 \mathrm{~mm}$. Particles $>2 \mathrm{~mm}$ were combined with the coarse stones. Dry weights of roots and com- 
bined stone fractions were determined. Total $\mathrm{N}$ and $\mathrm{C}$ concentrations in $<2 \mathrm{~mm}$ soil separates were determined using dry combustion (VarioMax, Elementar Analysensysteme GmbH, Hanau, Germany). As the site contains no carbonates, total $\mathrm{C}$ was assumed to equal organic $\mathrm{C}$. As bulk density varies spatially and over time (e.g. through compaction by livestock), the soil $\mathrm{N}$ and $\mathrm{C}$ content per unit ground area to a fixed depth will also change, without any change in the mass fraction of $\mathrm{N}$ and $\mathrm{C}$ in dry soil. Therefore, total $\mathrm{N}$ and $\mathrm{C}$ stocks were calculated on an equivalent soil mass (ESM) basis, so that comparisons between years were valid (see Gifford and Roderick, 2003; Wendt and Hauser, 2013). A cubic polynomial was fitted to the data to predict cumulative $\mathrm{N}$ and $\mathrm{C}$ with cumulative soil mass in the profile. A soil mass of $800 \mathrm{~kg} \mathrm{~m}^{-2}$ was used (Table 6), which corresponds to approximately $60 \mathrm{~cm}$ depth, which was the depth of the corer. Uncertainty in the estimates of stock change was based on the prediction intervals in the cubic polynomial at a soil mass of $800 \mathrm{~kg} \mathrm{~m}^{-2}$.

\subsection{Ancillary measurements}

Soil temperature and volumetric soil moisture were continuously recorded at four depths $(3.5,7.5,15$ and $30 \mathrm{~cm})$ by temperature probes (temperature probe 107, Campbell Scientific, Loughborough, UK) and time domain reflectometry (TDR) probes (TDR 100, Campbell Scientific, Loughborough, UK), the latter installed in June 2002. Rain was measured by a tipping-bucket rain gauge, while air temperature and relative humidity were measured by an integrated humidity and temperature transmitter (HUMITTER ${ }^{\circledR}$, Vaisala Ltd, Suffolk, UK).

\subsection{Statistical and uncertainty analysis}

Random error was determined as $2 \sigma$ standard error $(95 \%$ confidence) of the overall mean according to Gaussian statistics. The confidence intervals for group means were used to establish whether or not differences were significantly different from zero. Linear correlations between $\mathrm{C}$ and $\mathrm{N}$ inputs and outputs were calculated by calendar year. For systematic errors the uncertainty range of measurements as well as of parameterisations and literature-based estimates was estimated according to expert judgment. To calculate the combined effect of systematic uncertainties of each flux component on the $\mathrm{C}$ and $\mathrm{N}$ budget, simple Gaussian error propagation rules were used; details are provided in Table S1 (Supplement). Confidence intervals are given at the $95 \%$ confidence level.

Additional details of the methods are provided in the Supplement.

\section{Results}

\subsection{Climate and management}

The meteorological conditions exhibited substantial interannual variability in the study period 2002-2010 (Table 2). Annual rainfall ranged from 575 to $1238 \mathrm{~mm}$ with highest monthly rainfalls of $280 \mathrm{~mm} \mathrm{month}^{-1}$ in September 2002 . Lowest annual reported rainfall was in 2010; this low value was caused by a gap in data from January to March due to snowfall. Average annual air temperature ranged from 8.3 to $9.6^{\circ} \mathrm{C}$, with highest daily air temperatures of $30.4^{\circ} \mathrm{C}$ in $\mathrm{Au}-$ gust 2005 and lowest in December 2010 at $-10.3^{\circ} \mathrm{C}$. Highest average monthly air temperatures were measured in July 2006 at $17^{\circ} \mathrm{C}$ and lowest monthly average air temperatures at $2{ }^{\circ} \mathrm{C}$ in November 2009. In 2003 the highest average annual temperature $\left(9.6^{\circ} \mathrm{C}\right)$ and lowest annual rainfall $(680 \mathrm{~mm})$ were measured with a correspondingly low annual soil water content of $31 \%$. The duration of the growing season was defined per calendar year as the period bounded by the first and last 5 consecutive days with a mean daily air temperature $\geq 5^{\circ} \mathrm{C}$. The length of the growing season (LGS) varied between 151 days (2006) and 242 days (2009; Table 2).

Livestock stocking density exhibited both intra- and inter-annual variability. The average annual stocking densities were lowest in 2002 and 2003 at $0.27 \mathrm{LSU} \mathrm{ha}^{-1}$ and $0.54 \mathrm{LSU} \mathrm{ha}^{-1}$, respectively (Table 1 ), which were the years where the grass was cut for silage and no lambs were present in the field. In 2007, 2008, 2009 and 2010, no heifers were present in the field. Highest annual average stocking densities occurred in 2004 and 2007 at 0.99 and $0.91 \mathrm{LSU} \mathrm{ha}^{-1}$, respectively. Maximum monthly stocking density occurred in September 2006 at $13.8 \mathrm{LSU} \mathrm{ha}^{-1}$, while interim periods with no grazing at all were observed in all years (Fig. 1a). Mineral $\mathrm{N}$ fertiliser was applied split into three to five applications per year, ranging from 2.5 to $9.6 \mathrm{~g} \mathrm{~N} \mathrm{~m}^{-2}$ per application (Fig. 1b). Organic manure was applied in 2004 and 2005 as cattle slurry, spread at a rate of 6.9 and $15.8 \mathrm{~g} \mathrm{~N} \mathrm{~m}^{-2}$ per application, respectively, which resulted in a $\mathrm{C}$ input of 55.4 and $171.8 \mathrm{~g} \mathrm{C} \mathrm{m}^{-2}$ per application, respectively (Fig. $1 \mathrm{~b}$ and c). The grass was only cut in 2002 and 2003. Harvested biomass in 2002 and 2003 ranged from 2.60 to $3.75 \mathrm{tDW} \mathrm{ha}^{-1}$ per cut, which resulted in an $\mathrm{N}$ offtake ranging from 1.7 to $4.7 \mathrm{~g} \mathrm{~N} \mathrm{~m}^{-2}$ per cut and a $\mathrm{C}$ removal from the field ranging from 113.1 to $169.5 \mathrm{~g} \mathrm{C} \mathrm{m}^{-2}$ per cut (Fig. 1b and $\mathrm{c}$ ).

\subsection{N budget}

In our grassland system the $\mathrm{N}$ balance is the difference between the $\mathrm{N}$ input through fertiliser and atmospheric deposition and the $\mathrm{N}$ output through harvest, animal export, leaching and gaseous emissions. The total resulting balance over the 9 years, derived from flux calculations and estimations, showed that $\mathrm{N}$ was stored at an average rate 
Table 2. Weather characteristics of each measurement year.

\begin{tabular}{lrrrrrrrrr}
\hline & 2002 & 2003 & 2004 & 2005 & 2006 & 2007 & 2008 & 2009 & 2010 \\
\hline Annual mean temperature $\left({ }^{\circ} \mathrm{C}\right)$ & 9.2 & 9.6 & 8.9 & 8.8 & 9.3 & 9.1 & 8.6 & 8.9 & 8.3 \\
Maximum temperature $\left({ }^{\circ} \mathrm{C}\right)$ & 23.6 & 29.5 & 27.4 & 30.4 & 26.6 & 21.4 & 23.5 & 28.0 & 24.0 \\
Minimum temperature $\left({ }^{\circ} \mathrm{C}\right)$ & -5.1 & -8.4 & -4.9 & -6.6 & -5.5 & -7.5 & -5.8 & -7.8 & -10.3 \\
Annual rainfall (mm) & 1238 & 680 & 1169 & 1028 & 1120 & 904 & 1065 & 744 & 575 \\
Soil water content $(\%$ by volume) & 36.9 & 31.0 & 40.3 & 45.2 & 36.6 & 37.7 & 41.5 & 39.4 & - \\
Water-filled pore space $(\%)$ & 68.0 & 57.2 & 74.3 & 83.3 & 67.5 & 69.5 & 76.5 & 72.6 & - \\
Length of growing season* (days) & 180 & 196 & 156 & 177 & 151 & 186 & 193 & 242 & 226 \\
\hline
\end{tabular}

* The plant growing season begins and ends with periods of consecutive days, where daily temperatures average more than $5^{\circ} \mathrm{C}$ without any 5 -day spells of temperatures below $5^{\circ} \mathrm{C}$.

Table 3. Nitrogen budget and balance for each measurement year and average values, confidence intervals at $p>0.95$ (CI) and systematic uncertainties (uncert.) for 2002-2010 $\left(\mathrm{g} \mathrm{N} \mathrm{m}^{-2} \mathrm{a}^{-1}\right)$. Negative numbers represent uptake, while positive numbers represent loss of $\mathrm{N}$ from this grassland ecosystem. Letters indicate data published in previous publications.

\begin{tabular}{|c|c|c|c|c|c|c|c|c|c|c|c|c|}
\hline & \multirow[t]{2}{*}{2002} & \multirow[t]{2}{*}{2003} & \multirow[t]{2}{*}{2004} & \multirow[t]{2}{*}{2005} & \multirow[t]{2}{*}{2006} & \multirow[t]{2}{*}{2007} & \multirow[t]{2}{*}{2008} & \multirow[t]{2}{*}{2009} & \multirow[t]{2}{*}{2010} & \multicolumn{3}{|c|}{$2002-2010$} \\
\hline & & & & & & & & & & average & CI & uncert. \\
\hline Organic fertilisation & 0 & 0 & -6.9 & -15.8 & 0 & 0 & 0 & 0 & 0 & -2.5 & 3.6 & 0.2 \\
\hline Cake feed for ewes & 0 & 0 & -1.2 & -1.4 & -1.1 & -1.9 & -1.1 & -1.2 & -0.7 & -0.9 & 0.4 & 0.0 \\
\hline Wet deposition & -0.4 & -0.6 & -0.6 & -0.7 & -0.6 & -0.6 & -0.5 & -0.4 & -0.4 & -0.5 & 0.1 & 0.2 \\
\hline${ }^{a}$ Dry deposition & -0.5 & -0.4 & -0.3 & -0.3 & -0.2 & -0.3 & -0.2 & -0.2 & -0.2 & -0.3 & 0.1 & 0.2 \\
\hline Wool & 0 & 0 & 0.6 & 0.5 & 0.4 & 0.7 & 0.7 & 0.2 & 0.2 & 0.4 & 0.2 & 0.0 \\
\hline${ }^{\mathrm{b}}$ Leaching & 14.9 & 0.1 & 0.1 & 4.6 & 10.6 & 4.2 & 5.6 & 2.6 & 5.0 & 5.3 & 3.1 & 1.71 \\
\hline $\mathrm{N}_{2}$ & 3.7 & 2.2 & 1.3 & 1.7 & 2.8 & 3.0 & 3.3 & 4.1 & 3.6 & 2.9 & 0.6 & 0.8 \\
\hline${ }^{\mathrm{c}} \mathrm{N}_{2} \mathrm{O}$ & 1.1 & 0.1 & 0.1 & 0.4 & 0.9 & 1.3 & 0.8 & 0.4 & 0.4 & 0.6 & 0.3 & 0.2 \\
\hline $\mathrm{NO}_{x}($ soil $)$ & 0.3 & 0.1 & 0 & 0.1 & 0.2 & 0.2 & 0.3 & 0.1 & 0.1 & 0.2 & 0.1 & 0.1 \\
\hline
\end{tabular}

${ }^{a}$ Flechard et al. (2011): dry deposition, modelled average value of the 2 years 2007/2008. ${ }^{\mathrm{b}}$ Molina-Herrera et al. (2016): N leaching modelled 2005-2010. ${ }^{\mathrm{c}}$ Molina-Herrera et al. (2016): $\mathrm{N}_{2} \mathrm{O}$ fluxes modelled 2005-2010; Di Marco et al. (2004): $\mathrm{N}_{2} \mathrm{O}$ fluxes measured by eddy covariance (half-hourly) June 2002 to June 2003; Jones et al. (2011): $\mathrm{N}_{2} \mathrm{O}$ fluxes measured by eddy covariance (half-hourly) and chambers (hourly) during measurement campaigns in June 2003, March, May and July 2007 and May and July 2008; Flechard et al. (2007): annual $\mathrm{N}_{2} \mathrm{O}$ fluxes measured by eddy covariance in 2002/2003 and by chambers in 2004; Skiba et al. (2013): annual $\mathrm{N}_{2} \mathrm{O}$ fluxes measured by chambers from January 2007-September 2010.

of $-6.0 \pm 5.9 \mathrm{~g} \mathrm{~N} \mathrm{~m}^{-2} \mathrm{a}^{-1}(p<0.05)$. From 2003 to 2010 , $\mathrm{N}$ was stored at a rate of -1.2 to $-18.2 \mathrm{~g} \mathrm{~N} \mathrm{~m}^{-2} \mathrm{a}^{-1}$, whilst in $2002 \mathrm{~N}$ was lost at a rate of $13.2 \mathrm{~g} \mathrm{~N} \mathrm{~m}^{-2} \mathrm{a}^{-1}$ (Table 3). The major $\mathrm{N}$ input consisted of inorganic fertiliser, ranging from -11 to $-25.9 \mathrm{~g} \mathrm{~N} \mathrm{~m}^{-2} \mathrm{a}^{-1}$, averaging at $-19.4 \mathrm{~g} \mathrm{~N} \mathrm{~m}^{-2} \mathrm{a}^{-1}$, while $\mathrm{N}$ deposition represented only between 1.9 and $5.9 \%$ of the total $\mathrm{N}$ input. $\mathrm{N}$ input through standard cake feed given to ewes during lactation ranged between 1.1 and $1.9 \mathrm{~g} \mathrm{~N} \mathrm{~m}^{-2} \mathrm{a}^{-1}$. During the years when $\mathrm{N}$ was stored, a significant positive correlation between total $\mathrm{N}$ input from fertiliser and $\mathrm{N}$ storage was observed $\left(R^{2}=0.55\right)$. The largest losses resulted from leaching at an average rate of $5.34 \pm 3.1 \mathrm{~g} \mathrm{~N} \mathrm{~m}^{-2} \mathrm{a}^{-1}$ and were estimated to be the highest in 2002 at $14.9 \mathrm{~g} \mathrm{~N} \mathrm{~m}^{-2} \mathrm{a}^{-1}$ and the low- est in 2003 at $0.09 \mathrm{~g} \mathrm{~N} \mathrm{~m}^{2} \mathrm{a}^{-1}$. The total $\mathrm{N}$ offtake through meat and wool ranged from 0.15 to $3.12 \mathrm{~g} \mathrm{~N} \mathrm{~m}^{-2} \mathrm{a}^{-1}$, while the total annual $\mathrm{N}$ offtake from harvest was 11.8 in 2002 and $10.4 \mathrm{~g} \mathrm{~N} \mathrm{~m}^{-2} \mathrm{a}^{-1}$ in 2003. Amongst gaseous exchanges, the highest losses were estimated from $\mathrm{N}_{2}$ emissions, averaging at $2.9 \mathrm{~g} \mathrm{~N} \mathrm{~m}^{-2} \mathrm{a}^{-1}$ with maximum losses of $4.12 \mathrm{~g} \mathrm{~N} \mathrm{~m}^{-2} \mathrm{a}^{-1}$ in 2009, although in 2004 and 2005 losses from $\mathrm{NO}_{x}$ and $\mathrm{NH}_{3}$ volatilisation from excretion and organic fertilisation exceeded losses from $\mathrm{N}_{2}$ emissions. Losses through $\mathrm{NO}_{x}$ from the soil were always less than $1 \%$ of the total $\mathrm{N}$ exchange $\left(0.2 \mathrm{~g} \mathrm{~N} \mathrm{~m}^{-2} \mathrm{yr}^{-1}\right)$. Nitrous oxide emissions ranged from 0.11 to $1.27 \mathrm{~g} \mathrm{~N} \mathrm{~m}^{-2} \mathrm{a}^{-1}$, representing $1.3-8.4 \%$ of the total $\mathrm{N}$ export. Annual $\mathrm{N}_{2} \mathrm{O}$ emissions showed no correlation with precipitation, livestock density 
(a) $\mathrm{N}$ budget ( $\%$ total $\mathrm{N}$ input); harvested and grazed

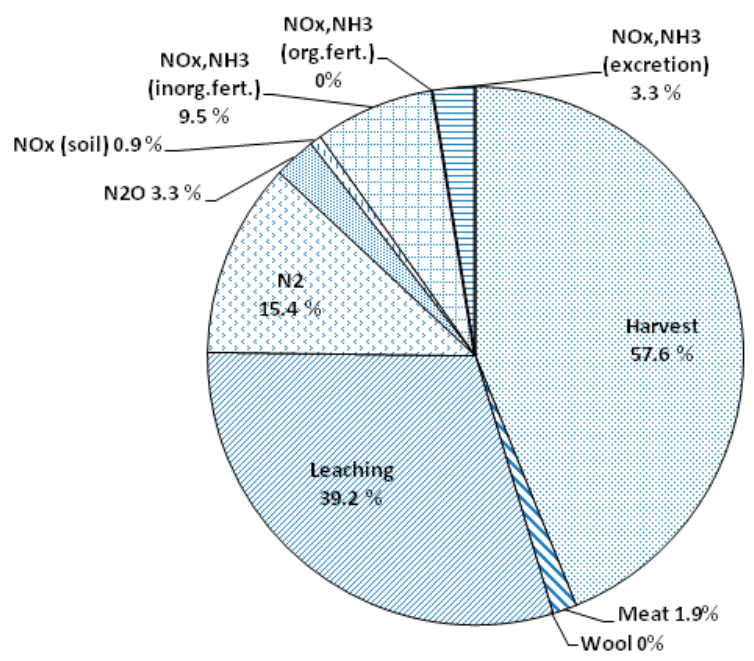

(b) $\mathrm{N}$ budget ( $\%$ total $\mathrm{N}$ input); grazed only

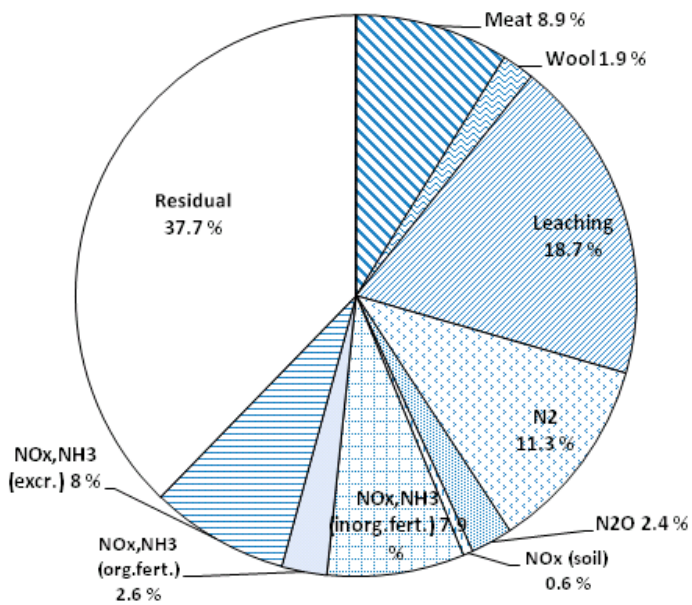

Figure 2. Mean annual nitrogen budget for Easter Bush, showing the fate of total N input (fertiliser and deposition) in (a) years when grass was harvested for silage (2002 and 2003) and (b) in years when only grazing took place (2004-2010). The residual term in (b) includes any net accumulation of soil organic nitrogen as well as all the error in the budget calculation.

Table 4. Carbon budget and balance for each measurement year and average values, confidence intervals at $p>0.95$ (CI) and systematic uncertainties (uncert.) for 2002-2010 $\left(\mathrm{g} \mathrm{C} \mathrm{m}^{-2} \mathrm{a}^{-1}\right)$. Negative numbers represent uptake, while positive numbers represent loss of $\mathrm{C}$ from the grassland ecosystem. Letters indicate data published in previous publications.

\begin{tabular}{|c|c|c|c|c|c|c|c|c|c|c|c|c|}
\hline & \multirow[t]{2}{*}{2002} & \multirow[t]{2}{*}{2003} & \multirow[t]{2}{*}{2004} & \multirow[t]{2}{*}{2005} & \multirow[t]{2}{*}{2006} & \multirow[t]{2}{*}{2007} & \multirow[t]{2}{*}{2008} & \multirow[t]{2}{*}{2009} & \multirow[t]{2}{*}{2010} & \multicolumn{3}{|c|}{ 2002-2010 } \\
\hline & & & & & & & & & & average & CI & uncert. \\
\hline GPP & -2162.9 & -1982.0 & -2111.4 & -1662.4 & -982.1 & -1722.7 & -1441.2 & -1722.4 & -2015.4 & -1755.8 & 244.4 & 105.3 \\
\hline TER & 1726.9 & 1725.9 & 2183.2 & 1638.5 & 972.1 & 1606.7 & 1324.0 & 1116.7 & 1547.0 & 1537.9 & 236.2 & 92.3 \\
\hline NPP & -1081.5 & -991.0 & -1055.7 & -831.2 & -491.1 & -861.3 & -720.6 & -861.2 & -1007.7 & -877.9 & 122.2 & -52.8 \\
\hline${ }^{\mathrm{a}} \mathrm{CO}_{2}$ (NEE) & -436.0 & -256.1 & 71.8 & -24.0 & -10.0 & -115.9 & -117.1 & -605.7 & -468.4 & -217.9 & 154.5 & 80.0 \\
\hline Organic fert. & 0.0 & 0.0 & -55.4 & -171.8 & 0.0 & 0.0 & 0.0 & 0.0 & 0.0 & -25.2 & 37.8 & 5.0 \\
\hline Harvest & 270.6 & 169.5 & 0.0 & 0.0 & 0.0 & 0.0 & 0.0 & 0.0 & 0.0 & 48.9 & 65.5 & 5.4 \\
\hline Meat (incl. bones) & 0.9 & 2.9 & 11.4 & 15.6 & 12.9 & 14.3 & 9.0 & 6.3 & 7.3 & 9.0 & 3.3 & 10 \\
\hline Wool & 0.0 & 0.0 & 1.7 & 1.5 & 1.3 & 2.1 & 2.0 & 0.7 & 0.5 & 1.1 & 0.5 & 0.1 \\
\hline${ }^{\mathrm{b}}$ Leaching & 25.1 & 7.0 & 22.1 & 18.7 & 19.4 & 17.0 & 17.0 & 6.8 & 14.3 & 16.6 & 4.3 & 5.3 \\
\hline $\mathrm{CH}_{4}$ (organic fert.) & 0.0 & 0.0 & 0.0 & 0.1 & 0.0 & 0.0 & 0.0 & 0.0 & 0.0 & 0.0 & 0.0 & 0.0 \\
\hline${ }^{\mathrm{c}} \mathrm{CH}_{4}$ (soil) & 0.0 & 0.0 & 0.0 & 0.0 & 0.1 & 0.1 & 0.0 & 0.0 & 0.0 & 0.0 & 0.0 & 0.1 \\
\hline $\mathrm{CH}_{4}$ (excretion) & 0.0 & 0.1 & 0.2 & 0.1 & 0.2 & 0.2 & 0.1 & 0.1 & 0.1 & 0.1 & 0.0 & 0.0 \\
\hline $\mathrm{CH}_{4}$ (enteric ferm.) & 1.5 & 3.2 & 5.7 & 4.8 & 5.2 & 5.2 & 4.8 & 4.1 & 3.8 & 4.3 & 0.8 & 0.9 \\
\hline $\mathrm{C}$ balance (NBP) & -137.8 & -73.3 & 57.6 & -154.9 & 29.1 & -77.2 & -84.1 & -587.7 & -440.3 & -163.2 & 139.5 & 16.0 \\
\hline
\end{tabular}

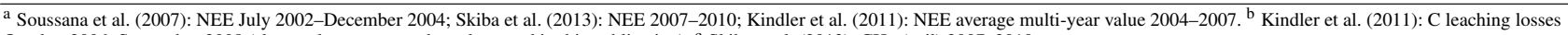
October 2006-September 2008 (slope value corresponds to data used in this publication). ${ }^{\mathrm{c}}$ Skiba et al. (2013): $\mathrm{CH}_{4}$ (soil) 2007-2010.

or total $\mathrm{N}$ input. $\mathrm{N}_{2} \mathrm{O}$ emission factors (percentage of $\mathrm{N}$ lost from total $\mathrm{N}$ inputs by mineral and organic fertiliser), ranged between 0.6 and $7.5 \%$ (Table 5).

To investigate the influence of different managements on the $\mathrm{N}$ and $\mathrm{C}$ budget, we separated experimental years into harvested and grazed (2002 and 2003) and grazed-only years (2004-2010, Figs. 2 and 3). During the harvested and grazed years, the main loss of $\mathrm{N}$ from the system occurred from the export through harvest (57.6\% of total $\mathrm{N}$ inputs), followed by leaching (39.2\%), while the export from animals (meat and wool) accounted for less than $2 \%$ of total $\mathrm{N}$ losses (Fig. 2a). The main loss to the atmosphere resulted from to- tal denitrification $\left(\mathrm{N}_{2} ; 15.4 \%\right)$, followed by $\mathrm{NO}_{x}$ and $\mathrm{NH}_{3}$ volatilisation from inorganic $\mathrm{N}$ fertiliser applications $(9.5 \%)$, while $\mathrm{N}_{2} \mathrm{O}$ emissions accounted for $3.3 \%, \mathrm{NO}_{x} / \mathrm{NH}_{3}$ volatilisation from excretion for $3.3 \%$ and $\mathrm{NO}_{x}$ from soil for less than $1 \%$. On average, $\mathrm{N}$ was lost from the grassland system during 2002 and 2003; The surplus of $31.3 \%$ (all outputs added up in Fig. 2a result in $131.3 \%$ ) represents the $\mathrm{N}$ lost from the soil as well as the error in the budget. When grazed-only years were considered (Fig. 2b), $\mathrm{N}$ was stored in the grassland system; the residual part, which includes the net accumulation of soil organic nitrogen and all the error in the budget, was $37.7 \%$. Losses through leaching (18.7\%) 
(a) C budget (\%NPP); harvested and grazed

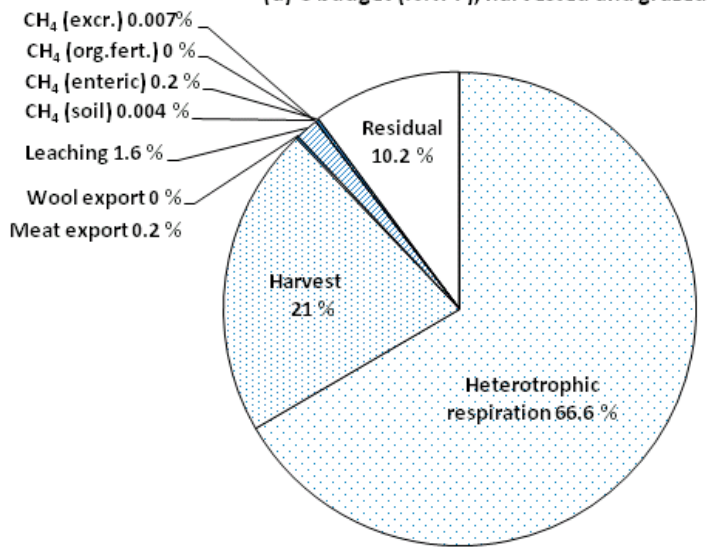

(b) C budget (\%NPP); grazed only

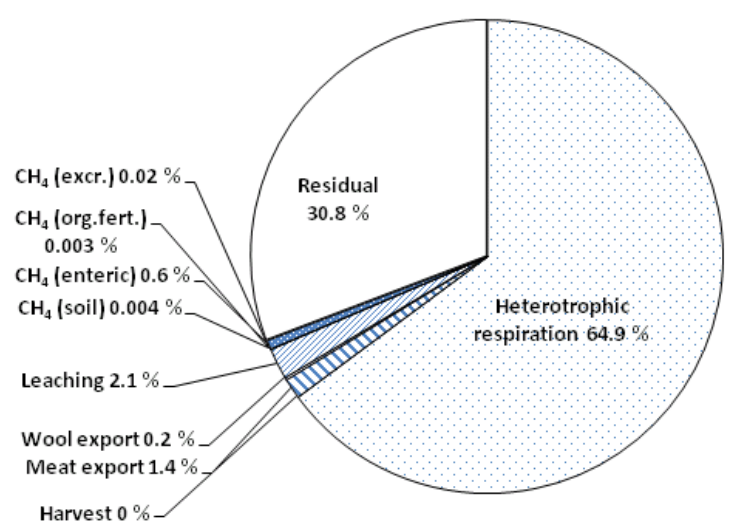

Figure 3. Mean annual carbon budget for Easter Bush, showing the fate of net primary productivity (NPP) in (a) years when grass was harvested for silage (2002 and 2003) and (b) in years when only grazing took place (2004-2010). Heterotrophic respiration includes the respiration of soil microbes, cows and sheep. The residual term includes all the error in the budget calculation, as well as any net accumulation of soil organic carbon.

Table 5. Annual $\mathrm{N}_{2} \mathrm{O}$ exchange, total $\mathrm{N}$ input by fertiliser (mineral and organic) and $\mathrm{N}_{2} \mathrm{O}$ emission factors, expressed as a percentage of total $\mathrm{N}$ inputs in 2002-2010.

\begin{tabular}{rrrr}
\hline & $\begin{array}{r}\mathrm{N}_{2} \mathrm{O} \text { flux } \\
\left(\mathrm{g} \mathrm{N} \mathrm{m}^{-2} \mathrm{a}^{-1}\right)\end{array}$ & $\begin{array}{r}\text { Total N input } \\
\left(\mathrm{g} \mathrm{N} \mathrm{m}^{-2} \mathrm{a}^{-1}\right)\end{array}$ & $\begin{array}{r}\mathrm{EF} \\
(\%)\end{array}$ \\
\hline 2002 & 1.14 & 20.60 & 5.5 \\
2003 & 0.14 & 15.98 & 0.9 \\
2004 & 0.11 & 11.00 & 0.6 \\
2005 & 0.36 & 17.25 & 1.1 \\
2006 & 0.88 & 22.43 & 3.9 \\
2007 & 1.25 & 17.25 & 7.2 \\
2008 & 0.84 & 25.93 & 3.2 \\
2009 & 0.41 & 24.95 & 1.6 \\
2010 & 0.35 & 18.98 & 1.9 \\
\hline
\end{tabular}

and $\mathrm{N}_{2}(11.3 \%)$ were lower in grazed years compared to harvested years, while the export through grazing animals was considerably higher at $18.8 \%$ (sum of $\mathrm{N}$ loss through meat, wool and $\mathrm{NO}_{x}$ and $\mathrm{NH}_{3}$ volatilisation from excretion). An additional loss occurred in grazed years through the volatilisation of $\mathrm{NO}_{x}$ and $\mathrm{NH}_{3}$ from organic fertiliser applications in 2004 and 2005 (2.6\%). Losses through $\mathrm{N}_{2} \mathrm{O}$ and $\mathrm{NO}_{x}$ and $\mathrm{NH}_{3}$ from inorganic fertiliser were comparable to harvested years at 2.4 and $7.9 \%$, respectively.

Cumulative soil $\mathrm{N}$ stocks were derived from soil core measurements taken in May 2004 and May 2011 (Table 6). In $2004 \mathrm{~N}$ stocks were $840.86( \pm 11.89) \mathrm{g} \mathrm{N} \mathrm{m}^{-2}$ and in 2011 they were $870.02( \pm 14.14) \mathrm{g} \mathrm{N} \mathrm{m}^{-2}$. Nitrogen storage over the 7 years was calculated from the cumulative equivalent soil mass (ESM) for the soil mass increment of $800 \mathrm{~kg} \mathrm{~m}^{-2}$, which corresponds to approximately $60 \mathrm{~cm}$ depth. The estimated $\mathrm{N}$ storage over the 7 years was

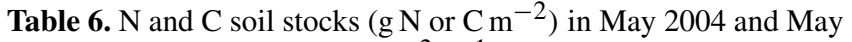
2011 and budgets $\left(\mathrm{g} \mathrm{N}\right.$ or $\mathrm{C} \mathrm{m}^{-2} \mathrm{a}^{-1}$ ) over 7 years based on repeated soil $\mathrm{N}$ and $\mathrm{C}$ stock inventories and flux budget calculations (January 2004-December 2010). Soil stock changes are based on a soil mass of $800 \mathrm{~kg} \mathrm{~m}^{-2}$, which corresponds to approximately $60 \mathrm{~cm}$ depth. The flux budgets are averages for the years 20042010 (Tables 4 and 5). Numbers in brackets represent confidence intervals. Negative numbers are sinks.

\begin{tabular}{lrr}
\hline & Nitrogen & Carbon \\
\hline Soil stocks in 2004 & $840.68(11.89)$ & $12026.05(190.19)$ \\
Soil stocks in 2011 & $870.02(14.14)$ & $11824.87(187.84)$ \\
Soil stock change & $-4.51(2.64)$ & $29.08(38.19)$ \\
Flux budget & $-9.40(4.14)$ & $-179.6(180.1)$ \\
\hline
\end{tabular}

$-4.51 \pm 2.64 \mathrm{~g} \mathrm{~N} \mathrm{~m}^{-2} \mathrm{a}^{-1}$ and was a significant $\mathrm{N}$ accumulation to the soil $(p<0.01)$. The estimated $\mathrm{N}$ storage derived from flux calculations between 2004 and 2010 was $-9.40 \pm 4.14 \mathrm{~g} \mathrm{~N} \mathrm{~m}^{-2} \mathrm{a}^{-1}$, which is almost 2 times more than that calculated by sequential soil analysis; however, values were not significantly different from each other.

\subsection{C budget}

Annual C inputs through photosynthesis (GPP) varied between -982.1 and $-2162.9 \mathrm{~g} \mathrm{C} \mathrm{m}^{-2}$, and losses through autotrophic and heterotrophic respiration (TER) varied between 972.1 and $2183.2 \mathrm{~g} \mathrm{C} \mathrm{m}^{-2}$, both considerably larger than any other C fluxes (Table 4). If only the NEE was considered (difference between GPP and TER), the grassland acted as a sink for $\mathrm{CO}_{2}$ at an average of $218 \pm 155 \mathrm{~g} \mathrm{C} \mathrm{m}^{-2} \mathrm{a}^{-1}$, and the $\mathrm{CO}_{2}$ uptake was significantly different from zero $(p<0.05)$. The sink strength ranged from -10 (2006) to 
$-606 \mathrm{~g} \mathrm{C} \mathrm{m}^{-2} \mathrm{a}^{-1}$ (2009); only in 2004, the grassland was a small source of $\mathrm{CO}_{2}\left(72 \mathrm{~g} \mathrm{C} \mathrm{m}^{-2} \mathrm{a}^{-1}\right)$. Taking into account all $\mathrm{C}$ inputs and outputs (NBP), $\mathrm{C}$ was sequestered on average at $163 \pm 140 \mathrm{~g} \mathrm{C} \mathrm{m}^{-2} \mathrm{a}^{-1}$ over the 9 years, although the storage was not significantly different from zero $(p<0.05)$. In 2004 and $2006 \mathrm{C}$ was lost from the ecosystem. The major $\mathrm{C}$ import resulted from NEE in all years apart from 2005, when the $\mathrm{C}$ input from manure application was larger. The highest $\mathrm{C}$ export occurred from harvest in 2002 and 2003 (270.6 and $169.5 \mathrm{~g} \mathrm{C} \mathrm{m}^{-2} \mathrm{a}^{-1}$, respectively), while the second-largest export in 2002 and 2003 and the largest exports in other years was leaching (6.8 to $25.1 \mathrm{~g} \mathrm{C} \mathrm{m}^{-2} \mathrm{a}^{-1}$ ). The measured $\mathrm{C}$ leaching value for $2007\left(17.0 \mathrm{~g} \mathrm{C} \mathrm{m}^{-2} \mathrm{a}^{-1}\right.$, Table 5) differs from the leaching value published for Easter Bush by Kindler et al. (2011), as we only used values of one of the two measured sites in this paper (slope, not hollow, as the hollow location was frequently water logged). The third largest C loss consisted of C export from meat in 2004-2010, ranging from 6.4 to $15.8 \mathrm{~g} \mathrm{C} \mathrm{m}^{-2} \mathrm{a}^{-1}$. In 2002 and 2003, when no lambs were present in the field, $\mathrm{C}$ export from meat was exceeded by $\mathrm{CH}_{4}$ losses from enteric fermentation. Carbon export from wool ranged from 0.5 to $2.1 \mathrm{~g} \mathrm{C} \mathrm{m}^{-2} \mathrm{a}^{-1}$. $\mathrm{CH}_{4}$ emissions from organic fertilisation, soil processes and animal excretion were always less than $1 \%$ of the total $\mathrm{C}$ losses. $\mathrm{CH}_{4}$ losses from enteric fermentation ranged from 1.5 to $5.7 \mathrm{~g} \mathrm{C} \mathrm{m}^{-2} \mathrm{a}^{-1}$, corresponding to $0.5-22.5 \%$ of all $\mathrm{C}$ losses from the ecosystem. The NBP was dominated by the NEE. A high livestock density tended to reduce the net sink strength. A significant negative correlation of NEE with stocking density could be seen $\left(R^{2}=0.47\right)$. The NBP correlated positively with rainfall $\left(R^{2}=0.48\right)$, and there was only a weak correlation between NEE and rainfall $\left(R^{2}=0.38\right)$.

The net primary production (NPP) in years when grass was harvested and grazed (2002 and 2003) and grazed only (2004-2010) are presented in Fig. 3. In both management types, most $\mathrm{C}$ was lost through ecosystem respiration, (67 and $65 \%$ of NPP, respectively). Harvest export represented $21 \%$ of NPP. Leaching accounted for $1.5 \%$ of NPP during harvested years and $2.1 \%$ in grazed-only years. Animal export (meat and wool) consisted of $1.6 \%$ of NPP in grazedonly years and was $0.2 \%$ of NPP in grazed and harvested years. The sum of all $\mathrm{CH}_{4}$ emissions (from organic fertilisation, excretion, enteric fermentation and soil) was less than $1 \%$ of the NPP. The residual part, which includes the $\mathrm{C}$ storage in the soil as well as the uncertainty of the budget, was estimated at 10 and $30.8 \%$ of NPP in harvested and grazed or grazed years, respectively.

The $\mathrm{C}$ content for the cumulative soil mass increment $\quad 0-800 \mathrm{~kg} \mathrm{~m}^{-2} \quad(\sim 0-60 \mathrm{~cm})$ was lower in $2011\left(12026.05 \pm 190.19 \mathrm{~g} \mathrm{C} \mathrm{m}^{-2}\right)$ compared to 2004 $\left(11824.87 \pm 187.84 \mathrm{~g} \mathrm{C} \mathrm{m}^{-2}\right)$, resulting in a $\mathrm{C}$ loss of $29.08 \pm 38.19 \mathrm{~g} \mathrm{C} \mathrm{m}^{-2}$ (Table 7). In comparison, based on flux calculations $\mathrm{C}$ was stored at $179.8 \pm 180 \mathrm{~g} \mathrm{C} \mathrm{m}^{-2} \mathrm{yr}^{-1}$ over the 7 years. However, neither $\mathrm{C}$ loss calculated by

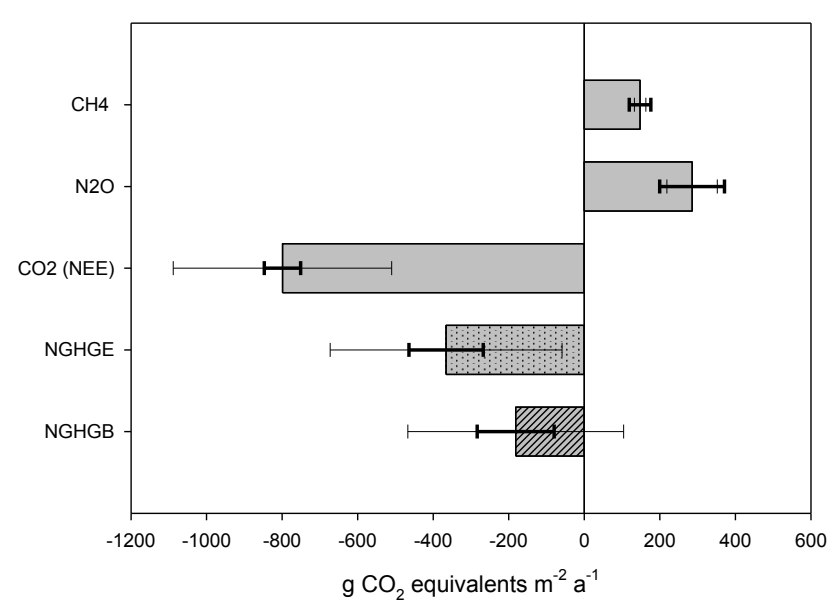

Figure 4. Average greenhouse gas fluxes, net GHG exchange (NGHGE) and attributed net GHG balance (NGHGB, includes $\mathrm{FC}_{\text {org fert }}, \mathrm{FC}_{\text {animal }}, \mathrm{FC}_{\text {leaching }}, \mathrm{FC}_{\text {harvest }}$ ) for 2002-2010. Positive values correspond to losses and negative values to storage of greenhouse gases to and from the grassland system. The $\mathrm{CH}_{4}$ component comprises $\mathrm{CH}_{4}$ fluxes from enteric fermentation, animal excretion, slurry application and soil exchange, while the $\mathrm{N}_{2} \mathrm{O}$ component is the $\mathrm{N}_{2} \mathrm{O}$ flux from the soil. $\mathrm{CO}_{2}$ represents the net ecosystem exchange (NEE). Global warming potentials of 298 and 25 were used for $\mathrm{N}_{2} \mathrm{O}$ and $\mathrm{CH}_{4}$, respectively, using a time horizon of 100 years (Myhre et al., 2013). Thin error bars represent variations (confidence intervals at $p>0.95$ ) between years, while thick error bars represent the systematic uncertainty of each value.

sequential soil analysis nor $\mathrm{C}$ storage estimated from flux calculations were significantly different from zero.

\subsection{Greenhouse gas budget}

Average greenhouse gas fluxes, NGHGE and NGHGB for 2002-2010 are shown in Fig. 4. The $\mathrm{CO}_{2}$ storage from the NEE provided the largest term in the annual GHG budget. Carbon dioxide (NEE) was sequestered over the 9 years at a rate of $-799 \pm 567 \mathrm{~g} \mathrm{CO}_{2} \mathrm{~m}^{-2} \mathrm{a}^{-1}$. This storage was significantly different from zero $(p<0.05)$. On average, NGHGE was highly correlated with annual NEE $\left(R^{2}=0.96\right)$. On average the grassland was a source of the GHGs $\mathrm{CH}_{4}$ and $\mathrm{N}_{2} \mathrm{O}$ at a rate of $148 \pm 30$ and $285 \pm 131 \mathrm{~g} \mathrm{CO}_{2} \mathrm{~m}^{-2} \mathrm{a}^{-1}$, respectively, both being significantly different from zero $(p<0.001$ and $p<0.01$, respectively). Nitrous oxide losses ranged from 52 (2004) to $588 \mathrm{~g} \mathrm{CO}_{2}$ eq. $\mathrm{m}^{-2} \mathrm{a}^{-1}$ (2007; data for each year not shown). Methane from soil processes, manure input and animal excretion accounted for less than $5 \%$ of total $\mathrm{CH}_{4}$ emissions. Methane emissions from enteric fermentation ranged from $53 \mathrm{~g} \mathrm{CO}_{2}$ eq. $\mathrm{m}^{-2} \mathrm{a}^{-1}$ (2002) to $199 \mathrm{~g} \mathrm{CO}_{2}$ eq. $\mathrm{m}^{-2} \mathrm{a}^{-1}$ (2004). Annual total $\mathrm{CH}_{4}$ emissions correlated positively with annual livestock density $\left(R^{2}=0.99\right)$. The $\mathrm{CH}_{4}$ emissions, which were predominately $(>97 \%)$ of ruminant origin weakened the sink strength of NEE by $18 \%$. If both $\mathrm{CH}_{4}$ and $\mathrm{N}_{2} \mathrm{O}$ were considered 
the total trade-off of NEE was a substantial $54 \%$ and increased to a total of $67 \%$ if only grazed years were considered. On average the grassland represented a GHG sink of $-366 \pm 601 \mathrm{~g} \mathrm{CO}_{2} \mathrm{~m}^{-2} \mathrm{a}^{-1}$ if only NEE, $\mathrm{CH}_{4}$ and $\mathrm{N}_{2} \mathrm{O}$ were included (NGHGE). If all $\mathrm{C}$ components $\left(\mathrm{FC}_{\text {org.fert }}\right.$, $\mathrm{FC}_{\text {animal }}, \mathrm{FC}_{\text {leaching }}, \mathrm{FC}_{\text {harvest }}$ ) are included, the sink strength of the grassland decreased to $-182 \pm 560 \mathrm{~g} \mathrm{CO}_{2} \mathrm{~m}^{-2} \mathrm{a}^{-1}$ (NGHGB). This represents a weakening of the sink strength of NGHGE by $50 \%$, mainly due to the export of harvest. However, it has to be noted that in harvested years the return of the manure, resulting from the grass fed to livestock off-site, would reduce the GHG balance. If only grazed years were considered the sink strength increased slightly by $5.4 \%$, due to the $\mathrm{C}$ input from manure in 2004 and 2005. Both NGHGE and NGHGB were not significantly different from zero.

\section{Discussion}

\subsection{Nitrogen balance}

The main $\mathrm{N}$ inputs in our study were from inorganic and organic fertiliser additions. The amount of $\mathrm{N}$ added through fertiliser was determined by national recommendations (SAC, 2013). Atmospheric $\mathrm{N}$ deposition (wet and dry) accounted only for a small fraction of the total $\mathrm{N}$ input to our managed grassland. This is in contrast to semi-natural systems, where atmospheric $\mathrm{N}$ deposition and biological fixation represents the main $\mathrm{N}$ input (Phoenix et al., 2006; Bleeker et al., 2011). Due to high $\mathrm{N}$ fertilisation rates and low soil $\mathrm{pH}$ the legume fraction was less than $1 \%$ and bio$\operatorname{logical} \mathrm{N}_{2}$ fixation therefore a negligible source of $\mathrm{N}$.

The data obtained from our budget were used to calculate the nitrogen use efficiency (NUE) expressed as the ratio between $\mathrm{N}$ in crop and animal products (in this case either the crop harvest or the sum of meat, wool and milk) and the total $\mathrm{N}$ inputs to the system (fertiliser, imported manure, standard cake concentrate fed to lactating ewes). The NUE of herbage in cut years (2002 and 2003) of $57.6 \%$ (Fig. 2a) is comparable to reported $\mathrm{N}$ efficiencies of $55-80 \%$ in harvested herbage from managed temperate grasslands (Ball and Ryden, 1984; Ammann et al., 2009). It has been shown that the NUE in crops is significantly higher compared to the NUE in animal production (Galloway and Cowling, 2002). The NUE of animal products on our grassland system ranged from 5 to $16.6 \%$ in grazed-only years (2004-2010), with an average of $9.9 \%$. This is in agreement with the NUE reported for sheep of $6.2 \%$ by Van der Hoek (1998) and beef production systems, which reported that $\mathrm{N}$ efficiencies range from 6 to $12 \%$ (Whitehead et al., 1986; Tyson et al., 1992) and 5$20 \%$ (Ball and Ryden, 1984). Approximately $85 \%$ of total harvested and imported $\mathrm{N}$ in the EU is used to feed livestock (Sutton et al., 2011; Leip et al., 2011). A measure to reduce
$\mathrm{N}$ pollution and GHG emissions could therefore be the reduction of meat consumption (Smith et al., 2013).

Nitrogen was lost from our grassland to the environment through different pathways. Nitrogen leaches from grassland soils in the form of nitrate $\left(\mathrm{NO}_{3}^{-}\right)$, ammonium $\left(\mathrm{NH}_{4}^{+}\right)$and dissolved organic $\mathrm{N}(\mathrm{DON})$. Overall, leaching from our field $\left(5.3 \pm 3.1 \mathrm{~g} \mathrm{~N} \mathrm{~m}^{-2} \mathrm{a}^{-1}\right)$ was comparable to values measured at intensively grazed pastures in Ireland (1.8-6.4 $\mathrm{g} \mathrm{N} \mathrm{m}^{-2} \mathrm{a}^{-1}$, Watson et al., 2007) and England (3.8-13.3 $\mathrm{g} \mathrm{N} \mathrm{m}^{-2} \mathrm{a}^{-1}$, Scholefield et al., 1993) or croplands (e.g. Bechmann et al., 1998, max. leaching losses of $\left.10.4 \mathrm{~g} \mathrm{~N} \mathrm{~m}^{-2} \mathrm{a}^{-1}\right)$. However, leaching from our study was high compared to the Swiss NitroEurope site, where a maximum loss of $0.35 \mathrm{~g} \mathrm{~N} \mathrm{~m}^{-2} \mathrm{a}^{-1}$ was estimated from an ungrazed grass-clover sward, despite comparable annual rainfall and $\mathrm{N}$ inputs from inorganic and organic fertiliser (Ammann et al., 2009). This difference can be explained by the different management of the two sites. Grazed grasslands tend to have higher $\mathrm{N}$ leaching rates than cut grasslands since herbage that is not cut and exported from the field in grazed grasslands but eaten by the grazing animals and returned as urinary $\mathrm{N}$ adds $\mathrm{N}$ to the system. Furthermore, the uneven distribution of excreted organic $\mathrm{N}$ further enhances leaching due to the formation of $\mathrm{N}$ hotspots, which has been observed at outdoor pig farms (e.g. Eriksen, 2001). Ryden et al. (1984a) showed a 5.6 times higher leaching loss from grazed compared to cut grassland with $36 \%$ of total $\mathrm{N}$ inputs lost from grazed compared to $6 \%$ lost from cut grassland. On our site $18.7 \%$ of total inputs was lost as leaching in grazed years, compared to $39 \%$ in the cut years. However, the higher value in cut years was due to the high rainfall in 2002.

Due to its high background in the atmosphere, $\mathrm{N}_{2}$ fluxes cannot be measured directly in the field. There are different methods to measure $\mathrm{N}_{2}$ fluxes indirectly, which have been summarised by Groffman et al. (2006). In our study, we estimated $\mathrm{N}_{2}$ losses using the process-based biogeochemical model LandscapeDNDC (Haas et al., 2013; Molina-Herrera et al., 2016). These losses represented the highest gaseous $\mathrm{N}$ losses from our grassland in most years, with an average of $12.6 \%$ of total $\mathrm{N}$ inputs and $14 \%$ of inorganic fertiliser $\mathrm{N}$ inputs. This is comparable with an average $\mathrm{N}_{2}$ loss of $12.5 \%$ from inorganic $\mathrm{N}$ applications measured by the acetylene inhibition method from a fertilised and cut but ungrazed grassland in Switzerland (Rudaz et al., 1999). Using the same method, Van der Salm et al. (2007) reported a higher loss of $22 \%$ of total $\mathrm{N}$ input from a cattle-grazed pasture on a heavy clay soil in the Netherlands. In addition to the impact of the heavy clay soil, which could have enhanced denitrification due to reduced oxygen concentrations, grazing is likely to have enhanced denitrification rates in Van der Salm's study. Grazing not only enhances denitrification through soil compaction caused by trampling animals but also through the formation of $\mathrm{N}$ hot spots resulting from unevenly distributed soil $\mathrm{N}$ from excretion. In our study $\mathrm{N}_{2}$ losses simulated by Land- 
scapeDNDC were based on average (per hectare) changes in the soil $\mathrm{N}$ pool instead of the more uneven distribution of soil $\mathrm{N}$ in hot spots like urine patches. Therefore, it is likely that $\mathrm{N}_{2}$ losses in our study have been underestimated, and better estimation would contribute to a significant reduction in the uncertainties associated with the overall $\mathrm{N}$ budget.

Annual $\mathrm{N}_{2} \mathrm{O}$ emissions measured in our study ( 0.1 to $1.3 \mathrm{~g} \mathrm{~N} \mathrm{~m}^{-2} \mathrm{a}^{-1}$ ) are within the range of literature values from reported grazed as well as ungrazed European grasslands (Leahy et al., 2004; Flechard et al., 2007). Generally $\mathrm{N}_{2} \mathrm{O}$ losses are higher from grazed grassland compared to cut, ungrazed pasture (Velthof and Oenema, 1995; Luo et al., 1999) due to a more anaerobic environment as a consequence of soil compaction caused by animal treading and the influence of $\mathrm{N}$ and $\mathrm{C}$ from the deposition of animal excreta to the soil. We did not observe any correlations between annual $\mathrm{N}_{2} \mathrm{O}$ emissions and total $\mathrm{N}$ input. We found a relationship between the cumulative precipitation 1 week before and 3 weeks after fertilisation with $\mathrm{N}_{2} \mathrm{O}$ emissions $\left(R^{2}=0.53\right.$; Skiba et al., 2013). This relationship, together with the influence of stocking density and the type of $\mathrm{N}$ applied (e.g. Jones et al., 2007; Flechard et al., 2007) needs to be considered when developing Tier $2 \mathrm{~N}_{2} \mathrm{O}$ emission factors. In our study emission factors (EFs) were above the uncertainty range $(0.3-3 \%)$ given by IPCC Tier 1 guidelines (IPCC, 2006b) in 4 out of 9 years. However, it has been shown that the $\mathrm{N}_{2} \mathrm{O}$ emission factor from managed grassland can be higher, especially under wet conditions and with a high soil C content as this is the case for Scottish soils (Jones et al., 2007; Dobbie et al., 1999; Buckingham et al., 2013).

In grazed pastures $\mathrm{NH}_{3}$ volatilises from urine patches, decomposing dung as well as from fertilisers containing urea and $\mathrm{NH}_{4}^{+}$(Twigg et al., 2011). Increased rates of $\mathrm{NH}_{3}$ losses have been associated with high stocking densities under a rotational grazing system by Ryden and Mc Neill (1984). In our study, $\mathrm{N}$ volatilised as $\mathrm{NH}_{3}$ and $\mathrm{NO}_{x}$ from inorganic and organic fertiliser and animal excretion accounted for a considerable amount of total N, with losses of $13 \%$ in cut and grazed years $(2002,2003)$ and $19 \%$ in grazed-only years. In contrast, soil $\mathrm{NO}_{x}$ emissions from our grassland were estimated to be negligible, accounting for less than $1 \%$ of the total budget. Soil $\mathrm{NO}_{x}$ emissions result predominantly from microbial nitrification of either added $\mathrm{N}$ fertilisers or following the mineralisation of soil organic matter, animal excretions or added manure. Emissions tend to be linked with aerobic soil conditions (Davidson, 1991).

Results from soil analysis taken in May 2004 and May 2011 indicate that our field has stored N $\left(-4.51 \pm 2.64 \mathrm{~g} \mathrm{~N} \mathrm{~m}^{-2} \mathrm{a}^{-1}\right)$. The $\mathrm{N}$ budget assessed from the net $\mathrm{N}$ flux balance showed that $\mathrm{N}$ was stored in the soil of our grassland over the same 7 years at a higher rate $\left(-9.40 \pm 4.14 \mathrm{~g} \mathrm{~N} \mathrm{~m}^{-2} \mathrm{a}^{-1}\right)$, although values were not significantly different from each other. The slight shifts in measurement periods (May 2004-May 2011) for the soil stock calculations and the period for flux budget calculations (January 2004-December 2010) is presumed to be insignificant in this comparison. Results from both methods are within the range of literature values. Neeteson and Hassink (1997) found an N accumulation in soil organic matter (SOM) of $0-25 \mathrm{~g} \mathrm{~N} \mathrm{~m}^{-2} \mathrm{a}^{-1}$ from two cattle-grazed farms in the Netherlands, while Watson et al. (2007) reported an $\mathrm{N}$ storage in grazed Irish grasslands ranging from 10 to $15.2 \mathrm{~g} \mathrm{~N} \mathrm{~m}^{-2} \mathrm{a}^{-1}$, depending on $\mathrm{N}$ inputs. Soil $\mathrm{N}$ storage assessed from soil measurements from a cut grassland close to our field, where plots were treated with cattle slurry, stored $\mathrm{N}$ over 6 years at a rate of $-2.17 \mathrm{~g} \mathrm{~N} \mathrm{~m}^{-2} \mathrm{a}^{-1}$ in the top $10 \mathrm{~cm}$, while, in the same experiment, an $\mathrm{N}$ loss was observed from mineral $\mathrm{N}$ and urea treatments $\left(4.5\right.$ and $8.3 \mathrm{~g} \mathrm{~N} \mathrm{~m}^{-1} \mathrm{a}^{-1}$, respectively; Jones et al., 2007). In contrast, Schipper et al. (2007) reported an average loss of $9.1 \mathrm{~g} \mathrm{~N} \mathrm{~m}^{-2} \mathrm{a}^{-1}$ in the top $100 \mathrm{~cm}$ from managed grasslands over 20 years in New Zealand. The reason for the small difference between methods (flux measurements vs. sequential soil sampling) in our study might lie in a possible underestimation of losses from flux measurements. Uncertainties of our estimates are high, especially those for $\mathrm{N}$ losses. The largest absolute systematic uncertainty for the $\mathrm{N}$ balance was attributed to $\mathrm{N}$ leaching as for most years values were modelled using data to evaluate the model from only one location. The uncertainty of the leaching estimate would therefore be reduced if the model could be validated with data measured from several locations. The second-highest systematic uncertainty was attributed to losses through $\mathrm{N}_{2}$, followed by $\mathrm{NO}_{x}$ and $\mathrm{NH}_{3}$ emission from excretion and $\mathrm{NO}_{x}$ and $\mathrm{NH}_{3}$ emission from inorganic fertilisation. Combined uncertainties from all components lead to a total systematic uncertainty in the $\mathrm{N}$ balance of $2.2 \mathrm{~g} \mathrm{~N} \mathrm{~m}^{-2} \mathrm{a}^{-1}$ (2004-2010).

\subsection{Carbon balance}

On an annual basis our grassland site was a sink for atmospheric $\mathrm{CO}_{2}$ in most years. NEE was only positive in 2004, which was likely to be due to a high livestock density. Generally, grazing causes a very gradual impact on the $\mathrm{CO}_{2}$ uptake as a part of the field is defoliated each day. The reduced leaf area index (LAI) then leads to a reduced $\mathrm{CO}_{2}$ uptake by plants. In addition to the reduced LAI, grazing presents a source of $\mathrm{CO}_{2}$ from animal respiration, thereby reducing the $\mathrm{CO}_{2}$ sink of the grassland within the field. The maximum uptake of $\mathrm{CO}_{2}$ measured in our study is close to the upper range of NEE reported for temperate grasslands (100 to $600 \mathrm{~g} \mathrm{C} \mathrm{m}^{-2} \mathrm{a}^{-1}$, IPCC, 1996). On average over the 9 years, the magnitude of the NEE on our grassland $\left(-218.0 \pm 154.5 \mathrm{~g} \mathrm{C} \mathrm{m}^{-2} \mathrm{a}^{-1}\right)$ was close to the average NEE measured in a comparison of nine $\mathrm{Eu}-$ ropean grasslands over 2 years $\left(240 \pm 70 \mathrm{~g} \mathrm{C} \mathrm{m}^{-2} \mathrm{a}^{-1}\right)$ by Soussana et al. (2007) and comparable to the $\mathrm{CO}_{2}$ sink capacity of managed Irish grasslands measured by Byrne et al. (2007) $\left(290 \pm 50 \mathrm{~g} \mathrm{C} \mathrm{m}^{-2} \mathrm{a}^{-1}\right)$ and Leahy et al. (2004) $\left(257 \mathrm{~g} \mathrm{C} \mathrm{m}^{-2} \mathrm{a}^{-1}\right)$. Despite high variability over the 9 years, 
the average NEE value was significantly different from zero $(p<0.05)$. The range of the calculated annual gross primary production (GPP; -982 to $-2163 \mathrm{~g} \mathrm{C} \mathrm{m}^{-2} \mathrm{a}^{-1}$ ) and terrestrial ecosystem respiration (TER; 972 to $2183 \mathrm{~g} \mathrm{C} \mathrm{m}^{-2} \mathrm{a}^{-1}$ ) from our field was within reported values for other managed grasslands. Gilmanov et al. (2007) reported the GPP of 18 intensively managed European grasslands ranging from 467 to $1874 \mathrm{~g} \mathrm{C} \mathrm{m}^{-2} \mathrm{a}^{-1}$ and TER ranging from 493 to $1541 \mathrm{~g} \mathrm{C} \mathrm{m}^{-2} \mathrm{a}^{-1}$, while Mudge et al. (2011) reported values of $2000 \mathrm{~g} \mathrm{C} \mathrm{m}^{-2} \mathrm{a}^{-1}$ for GPP and TER from an intensively grazed dairy pasture in New Zealand.

When all components of $\mathrm{C}$ import and export were included in addition to the $\mathrm{CO}_{2}$ exchange (NBP), $\mathrm{C}$ was stored in our grassland over the 9 years. However, due to the high variability between years, NBP was not significantly different from zero $(p=0.05)$, suggesting that our site is carbon neutral. The average $\mathrm{C}$ storage value on our site $\left(163 \pm 140 \mathrm{~g} \mathrm{C} \mathrm{m}^{-2} \mathrm{a}^{-1}\right)$ is higher than most estimates reported in the literature, but due to the high annual variation, still within the range of reported values; Soussana et al. (2007) reported C storage estimates from European grazed and cut grasslands of $104 \pm 73 \mathrm{~g} \mathrm{C} \mathrm{m}^{-2} \mathrm{a}^{-1}$, and Mudge et al. (2011) reported fluxes of $59 \pm 56$ and $90 \pm 56 \mathrm{~g} \mathrm{C} \mathrm{m}^{-2} \mathrm{a}^{-1}$ in 2 consecutive years for a grazed and cut grassland in New Zealand. NBP estimates from a Swiss grassland cut for silage was shown to sequester $\mathrm{C}$ at a rate of $147 \pm 130 \mathrm{~g} \mathrm{C} \mathrm{m}^{-2} \mathrm{a}^{-1}$ (Ammann et al., 2007), while estimates from a cut grassland in Germany were shown to vary from being a sink $\left(-28 \mathrm{~g} \mathrm{C} \mathrm{m}^{-2} \mathrm{a}^{-1}\right)$ to being a source of $\mathrm{C}\left(+25 \mathrm{~g} \mathrm{C} \mathrm{m}^{-2} \mathrm{a}^{-1}\right)$, depending on years (Prescher et al., 2010). The inclusion of all $C$ imports and exports leads to a weakening of the $C$ sink strength assessed from NEE measurements in 5 years and even changed the grassland from being a sink to being a source in 2006. Due to the C export from harvest, as well as the stimulation of primary production through grazing, $\mathrm{C}$ sequestration tends to be lower in cut compared to grazed systems (Soussana et al., 2004). This is represented in our study in the lower residual value of NPP in cut years compared to the residual value from grazedonly years (Fig. 3), where the residual value represents the $\mathrm{C}$ storage in the soil as well as the uncertainty of the budget. However, it has to be kept in mind that the herbage yielded from cuts will end up as animal feed; $\mathrm{C}$ will be digested and respired off-site, releasing $\mathrm{CO}_{2}$ and $\mathrm{CH}_{4}$ to the atmosphere as well as being returned to the grassland as manure.

Results from soil analysis indicate that our grassland has lost $\mathrm{C}$ from 2004-2010 (29 $\pm 38 \mathrm{~g} \mathrm{C} \mathrm{m}^{-2} \mathrm{a}^{-1}$, Table 6). In the literature, losses as well as storage of $\mathrm{C}$ at various rates have been reported for managed grasslands assessed from soil stock measurements. Soil stock change measurements from our field are comparable with values found in the literature. Depending on the study, managed grasslands in Belgium were shown to either lose $\left(90 \mathrm{~g} \mathrm{C} \mathrm{m}^{-2} \mathrm{a}^{-1}\right.$, Lettens et al., 2005a) or sequester carbon $\left(4.4 \mathrm{~g} \mathrm{C} \mathrm{m}^{-2} \mathrm{a}^{-1}\right.$ in 0 $30 \mathrm{~cm}$, Goidts and Van Wesemael, 2007; $22.5 \mathrm{~g} \mathrm{C} \mathrm{m}^{-2} \mathrm{a}^{-1}$ in
0-30 cm, Lettens et al., 2005b). Schipper et al. (2007) reported losses of $\mathrm{C}$ from pastures in New Zealand at an average rate of $106 \mathrm{~g} \mathrm{C} \mathrm{m}^{-2} \mathrm{a}^{-1}$ (top $100 \mathrm{~cm}$ ) over 20 years, but these losses were a result of an earlier land use change from forestry. Schuman, et al. (2002) measured a C sequestration of $10-30 \mathrm{~g} \mathrm{C} \mathrm{m}^{-2} \mathrm{a}^{-1}$ from US rangelands $(0-60 \mathrm{~cm})$, while Watson et al. (2007) measured a C storage at 112 $145 \mathrm{~g} \mathrm{C} \mathrm{m}^{-2} \mathrm{a}^{-1}$ in the top $15 \mathrm{~cm}$ soil layer from a grazed Irish grassland. Bellamy et al. (2005) showed no evidence of increased $\mathrm{C}$ in the topsoil of grasslands in England and Hopkins et al. (2009) found no significant change in SOC over time in two long-term UK experiments. The abovementioned results are contrasting and inconclusive because observed $\mathrm{C}$ sinks in grasslands are the effect of land management or land use change prior to the beginning of the C stock change measurement. Soussana et al. (2014) concluded in a theoretical study that grassland SOC sequestration has a strong potential to partly mitigate the GHG balance of ruminant production systems at low grazing intensities but not with intensive systems. Smith (2014) examined evidence from repeated soil surveys, long-term grassland experiments and simple mass balance calculations and concluded that, although grasslands can act as $\mathrm{C}$ sinks, they cannot act as a perpetual $\mathrm{C}$ sink and thus could not be used as an offset for GHG emissions.

The comparison of the $\mathrm{C}$ storage calculated from the net $\mathrm{C}$ flux balance with soil $\mathrm{C}$ stock changes shows that the flux balance estimated a $\mathrm{C}$ sequestration, while, based on $\mathrm{C}$ stock changes, $\mathrm{C}$ was lost, although neither value was significantly different from zero (Table 6). A literature search by Soussana et al. (2010) showed that generally C sequestration calculations on grassland were lower if derived from SOC stock changes (average $-5 \pm 30 \mathrm{~g} \mathrm{C} \mathrm{m}^{-2} \mathrm{a}^{-1}$ ) compared to $\mathrm{C}$ flux balances (average $-22 \pm 56 \mathrm{~g} \mathrm{C} \mathrm{m}^{-2} \mathrm{a}^{-1}$ ), although these estimates were not significantly different from each other. However, in none of those reviewed studies were $\mathrm{C}$ flux and $\mathrm{C}$ stock change measured in the same field experiment. A reason for the discrepancy between estimation methods in our study might lie in a possible underestimation of $\mathrm{C}$ exports in the flux balance calculation, leading to an overestimation of $\mathrm{C}$ storage in the soil. One underestimated flux could be the export of DIC and DOC. Carbon leaching from managed grasslands has not been reported in many studies. Kindler et al. (2011) reported C leaching from various European ecosystems, where the measured data (2007) from our experimental field were part of the study. Our data $\left(30.0 \mathrm{~g} \mathrm{C} \mathrm{m}^{-1} \mathrm{a}^{-1}\right.$, average of two locations as published in Kindler et al., 2011) were close to the average value $\left(29.4 \mathrm{~g} \mathrm{C} \mathrm{m}^{-1} \mathrm{a}^{-1}\right)$ of the reported European grasslands, which showed a range of $\mathrm{C}$ losses of 6.5$42.5 \mathrm{~g} \mathrm{C} \mathrm{m}^{-1} \mathrm{a}^{-1}$. Higher losses have been observed by McTiernan et al. (2001), who measured DOC export from grassland lysimeter plots treated with $\mathrm{N}$ fertiliser and slurry over 2 months. Up-scaled to 1 year, they measured DOC loss between 25.2 and $70.8 \mathrm{~g} \mathrm{C} \mathrm{m}^{-2} \mathrm{a}^{-1}$, all above what we mea- 
sured in our study. Important factors controlling the magnitude of $\mathrm{C}$ leaching have been shown to be drainage, the topsoil $\mathrm{C} / \mathrm{N}$ ratio and the saturation of the subsoil's sorption capacity for organic C (Kindler et al., 2011; McTiernan et al., 2001). In waterlogged soils the SOM decomposition and groundwater recharge tend to be reduced and thus the amount of $\mathrm{C}$ prone to leaching compared to that under more aerobic conditions associated with drainage. Although our field was drained more than 50 years ago, the drainage system does not operate very well, resulting in large puddles of standing water during prolonged periods of rain. The measured data used for the budget were taken at one sampling point, which was not in a waterlogged area. The spatial heterogeneity within the grassland field caused by uneven water management as well as faeces and urine patches requires us to sample at more points in order to obtain a representative leaching value. Therefore our leaching estimates are highly uncertain and could be significantly lower and $\mathrm{C}$ exports overestimated. Furthermore, leaching was only measured in 1 year (2007), while values for remaining years were estimated using a simple regression model with an attributed high uncertainty of $32 \%$ (5.3 $\mathrm{g} \mathrm{C} \mathrm{m}^{-2} \mathrm{a}^{-1}$ of average fluxes). Indeed, Siemens (2003) hypothesised that the underestimation of $\mathrm{C}$ leaching from soils can explain a large part of the difference between atmosphere- and land-based estimates of the $\mathrm{C}$ uptake of European terrestrial ecosystems. Another underestimated flux could be the loss of $\mathrm{CO}_{2}$ in the NEE measurements. Gap filling can introduce uncertainties in the NEE data especially for years with low data capture. Furthermore, $\mathrm{CO}_{2}$ losses from animal respiration could be underestimated at times due to the animals moving out of the footprint of the EC mast. Using animal respiration values from chamber experiments of 12.1 for cows and $11.7 \mathrm{~g} \mathrm{CO}_{2} \mathrm{~kg}^{-1}$ live weight d $\mathrm{d}^{-1}$ for sheep and lambs (S. Troy, SRUC, personal communication, 2014), we estimated a maximum $\mathrm{CO}_{2}$ loss from animal respiration of 53 (2002-2010) or $59 \mathrm{~g} \mathrm{C} \mathrm{m}^{-2} \mathrm{a}^{-1}$ (20042010). So if we assume that all animal respiration has been missed by eddy covariance measurements then the $\mathrm{C}$ sink estimated from NEE measurements would be reduced by 24 (2002-2010) or 33\% (2004-2010). This theoretical maximum $33 \%$ reduction would reduce the net carbon balance to $\sim 122 \mathrm{~g} \mathrm{C} \mathrm{m}^{-2} \mathrm{a}^{-1}$ (2004-2010).

In addition to uncertainties in the flux budget calculations, uncertainties are also attributed to soil $\mathrm{C}$ and $\mathrm{N}$ stock measurements. Soil inventory data in our study indicated a loss of $\mathrm{C}$ and a storage of $\mathrm{N}$ over 7 years, which seems contradictory, although $\mathrm{C}$ loss was not significantly different from zero. The uncertainty of soil $\mathrm{C}$ and $\mathrm{N}$ stock measurements arises from the variability of soil $\mathrm{C}$ and $\mathrm{N}$ concentrations due to errors from laboratory and to their high spatial variability as well as from the variability in the rock fragment content (Goidts et al., 2009).

\subsection{Greenhouse gas budget}

In the overall $\mathrm{N}$ and $\mathrm{C}$, budget $\mathrm{N}_{2} \mathrm{O}$ and $\mathrm{CH}_{4}$ emissions were negligible in terms of $\mathrm{N}$ and $\mathrm{C}$ losses from the system (1$8 \%$ of total $\mathrm{N}$ losses and $0.6-4.5 \%$ of total $\mathrm{C}$ losses). However, in terms of $\mathrm{CO}_{2}$ equivalents, $\mathrm{N}_{2} \mathrm{O}$ emissions as well as $\mathrm{CH}_{4}$ emissions strongly affected the GHG budget. Indeed, the sink strength of the NEE was weakened by $\mathrm{N}_{2} \mathrm{O}$ emissions by $29 \%$ over all years. Methane emissions from soil processes, manure input and animal excretion were negligible in terms of the $\mathrm{C}$ budget as well as in the GHG budget. In contrast, enteric fermentation proved to be an important GHG source. Methane emissions were also measured by eddy covariance technique over several months in 2010 on the same field (Dengel et al., 2011). By dividing $\mathrm{CH}_{4}$ fluxes by the number of sheep in the field each day, Dengel et al. (2011) calculated $\mathrm{CH}_{4}$ emissions per head of livestock as $7.4 \mathrm{~kg} \mathrm{CH}_{4}$ head $^{-1} \mathrm{a}^{-1}$ for sheep, which is close to the emission factor used in our budget of $7.6 \mathrm{~kg} \mathrm{CH}_{4}$ head $^{-1} \mathrm{a}^{-1}$ for ewes, showing that our estimates were realistic. The positive correlation of $\mathrm{CH}_{4}$ emissions with the stock density indicates that any changes in animal production will have a major impact on the global $\mathrm{CH}_{4}$ budget. The weakening of the GHG sink strength of the NEE by $\mathrm{N}_{2} \mathrm{O}$ and $\mathrm{CH}_{4}$ emissions, show the importance of those two gases in terms of global warming. Thus, adapting the management of grasslands by adding fertiliser or manure to increase plant growth and thus improve $\mathrm{C}$ sequestration in soils may increase $\mathrm{N}_{2} \mathrm{O}$ emissions, while changing land use from cropland to pasture in the attempt to reduce $\mathrm{C}$ losses from soils might lead to increased $\mathrm{CH}_{4}$ losses from grazing animals.

\section{Conclusions}

In our study only a small proportion of the $\mathrm{N}$ inputs from inorganic fertiliser and organic manure were converted to animal outputs or stored in the soil, while the main part was lost through leaching and gaseous emissions. An improvement of the NUE would mean both an economic profit for the farmer as well as an environmental benefit. Estimates from flux budget calculations indicated that our grassland was sequestering C. However, although grasslands can act as $\mathrm{C}$ sinks, they cannot act as a perpetual $\mathrm{C}$ sink and thus could not be used as an offset for GHG emissions (Smith et al., 2014). Instead, as it is easier and faster for soils to lose than to gain carbon, care must be taken to reduce $\mathrm{C}$ loss by management options, rather than trying to increase carbon stocks in grasslands. There was a discrepancy between soil stock measurements and flux budget calculations for the $\mathrm{C}$ as well as the $\mathrm{N}$ budget. The reason for the discrepancy between $\mathrm{C}$ budget estimates might lie in a possible underestimation of $\mathrm{C}$ exports such as leaching and animal respiration as well as the uncertainty due to gap filling in the NEE data. The $\mathrm{N}$ accumulation might have been overestimated by the flux calcula- 
tions through a possible overestimation of $\mathrm{N}$ losses, mainly through leaching as well as through $\mathrm{N}_{2}$ and $\mathrm{NO}_{x}$ and $\mathrm{NH}_{3}$ emissions. Furthermore, uncertainties are also attributed to soil $\mathrm{C}$ and $\mathrm{N}$ stock measurements. Our data have shown that the information about the potential of managed grasslands to act as sinks or sources for GHG is important for mitigation and adaption purposes. High plant productivity, stimulated by fertilisation, resulted in high plant $\mathrm{CO}_{2}$ fixation. However, increased $\mathrm{N}$ losses through $\mathrm{N}_{2} \mathrm{O}$ emissions counteracted the benefits of $\mathrm{C}$ sequestration in terms of GHG emissions. Furthermore, $\mathrm{CH}_{4}$ emissions from enteric fermentation largely reduced the positive effect of $\mathrm{CO}_{2}$ uptake, especially in years where NEE rates were small. We therefore conclude that $\mathrm{CO}_{2}$ exchange alone is not sufficient for the estimation of the GWP of a managed grassland ecosystem. Only a comprehensive approach, combining $\mathrm{C}$ and $\mathrm{N}$ cycling will help us to better understand functionalities of ecosystems and to improve modelling by integrating this knowledge.

Data availability. Data are available through the Environmental Information Data Centre (EIDC; Jones et al., 2017), a Natural Environment Research Council data centre hosted by the Centre for Ecology \& Hydrology (CEH), UK, as well as through the Nitroeurope database (data for 2006-2010, http://www.nitroeurope. eu/data_ext) and the Carboeurope database (data for 2004-2008, http://www.carboeurope.org/)

\section{The Supplement related to this article is available online at doi:10.5194/bg-14-2069-2017-supplement.}

Competing interests. The authors declare that they have no conflict of interest.

Acknowledgements. We would like to thank Chris Flechard for help with $\mathrm{N}$ deposition modelling, Patricia Ricci for help with the IPCC methodology used for $\mathrm{CH}_{4}$ animal emissions and $\mathrm{NO}_{x}$ and $\mathrm{NH}_{3}$ volatilisation calculations, and Sue Owen for help with VOC emission calculations. We are grateful to Ivan Simmons, Julia Drewer and Ian Leith for their help with field infrastructure. The authors gratefully acknowledge funding from the EU project GREENGRASS (EC EVK2-CT2001-00105), the NitroEurope Integrated Project (contract 017841) and CarboEurope (contract no. GOCE-CT-2003-505572).

Edited by: E. Veldkamp

Reviewed by: two anonymous referees

\section{References}

Ammann, C., Flechard, C. R., Leifeld, J., Neftel, A., and Fuhrer, J.: The carbon budget of newly established temperate grassland depends on management intensity, Agr. Ecosyst. Environ., 121, 5-20, 2007.

Ammann, C., Spirig, C, Leifeld. J., and Neftel, A.: Assessment of the nitrogen and carbon budget of two managed temperate grassland fields, Agr. Ecosyst. Environ., 133, 150-162, 2009.

Amthor, J. S.: The McCree-de Wit-Penning de Vries-Thornley Respiration Paradigms: 30 Years Later, Ann. Bot., 86, 1-20, 2000.

Aubinet, M., Grelle, A., Ibrom, A., Rannik, U., Moncrieff, J., Foken, T., Kowalski, A. S., Martin, P. H., Berbigier, P., Bernhofer, C., Clement, R., Elbers, J., Granier, A., Grunwald, T., Morgenstern, K., Pilegaard, K., Rebmann, C., Snijders, W., Valentini, R., and Vesala, T.: Estimates of the annual net carbon and water exchange of forests: The EUROFLUX methodology, Adv. Ecol. Res., 30, 113-175, 2000.

Ball, P. R. and Ryden. J. C.: Nitrogen Relationships in Intensively Managed Temperate Grasslands, Plant Soil, 76, 23-33, 1984.

Bechmann, M., Eggestad, H. O., and Vagstad, N.: Nitrogen balances and leaching in four agricultural catchments in southeastern Norway, Environ. Pollut., 102, 493-99, 1998.

Bellamy, P. H., Loveland, P. J., Bradley, R. I., Lark R. M., and Kirk, G. J. D.: Carbon losses from all soils across England and Wales 1978-2003, Nature, 437, 245-248, 2005.

Bleeker, A., Hicks, W. K., Dentener, F., Galloway, J., and Erisman, J. W.: N deposition as a threat to the World's protected areas under the Convention on Biological Diversity, Environ. Pollut. 159, 2280-2288, 2011.

Braun-Blanquet J.: Pflanzensoziologie, Grundzüge der Vegetationskunde, 3. Aufl., Springer, Verlag, Wien and New York, 1964.

Byrne, K. A., Kiely, G., and Leahy, P: Carbon sequestration determined using farm scale carbon balance and eddy covariance, Agr. Ecosyst. Environ., 121, 357-364, 2007.

Buckingham, S., Rees, R. M., and Watson, C. A.: Issues and pressures facing the future of soil carbon stocks with particular emphasis on Scottish soils, J. Agr. Sci., 152, 699-715, 2013.

Butterbach-Bahl, K., Gasche, R., Breuer, L., and Papen, H.: Fluxes of $\mathrm{NO}$ and $\mathrm{N}_{2} \mathrm{O}$ from temperate forest soils: impact of forest type, $\mathrm{N}$ deposition and of liming on the $\mathrm{NO}$ and $\mathrm{N}_{2} \mathrm{O}$ emissions, Nutr. Cycl. Agroecosys., 48, 79-90, 1997.

Caro, D., Davis S. J., Bastianoni, S., and Caldeira K.: Global and regional trends in greenhouse gas emissions from livestock, Climatic Change, 126, 203-216, 2014.

Chen, W., McCaughey, W. P., and Grant, C. A: Pasture type and fertilization effects on $\mathrm{N}-2$ fixation, $\mathrm{N}$ budgets and external energy inputs in western Canada, Soil. Biol. Biochem., 36, 1205-1212, 2004.

Clayton, H., Arah, J. R. M., and Smith, K. A.: Measurement of Nitrous-Oxide Emissions from Fertilized Grassland Using Closed Chambers, J. Geophys. Res.-Atmos., 99, 16599-165607, 1994.

Davidson, E. A.: Fluxes of nitrous oxide and nitric oxide from terrestrial ecosystems, in: Microbial Production and Consumption of Greenhouse Gases: Methane, Nitrogen Oxides and Halomethanes, edited by: Rogers, J. E. and Whitman, W. B., American Society of Microbiology, Washington, DC, 219-236, 1991.

Davison, B., Brunner, A., Ammann, C., Spirig, C., Jocher, M., and Neftel, A.: Cut-induced VOC emissions from agricultural grasslands, Plant Biol., 10, 76-85, 2008. 
Dengel, S., Levy, P. E., Grace, J., Jones, S. K., and Skiba, U. M.: Methane emissions from sheep pasture, measured with an openpath eddy covariance system, Glob. Change Biol., 17, 35243533, 2011.

Di Marco, C., Skiba, U., Weston ,K., Hargreaves, K., and Fowler, D.: Field scale $\mathrm{N}_{2} \mathrm{O}$ flux measurements from grassland using eddy covariance, Water Air Soil Poll., 4, 143-149, 2004.

Dobbie, K. E., McTaggart, I. P., and Smith, K. A.: Nitrous oxide emissions from intensive agricultural systems: Variations between crops and seasons, key driving variables, and mean emission factors, J. Geophys. Res.-Atmos., 104, 26891-26899, 1999.

Eriksen, J.: Nitrate leaching and growth of cereal crops following cultivation of contrasting temporary grasslands, J. Agr. Sci., 136, 271-281, 2001.

FAOSTAT: FAO online database, available at: http://faostat.fao.org, 2008.

Flechard, C. R., Ambus, P., Skiba, U., Rees, R. M., Hensen, A., van Amstel, A., Pol-van Dasselaar, A. V., Soussana, J. F., Jones, M., Clifton-Brown, J., Raschi, A., Horvath, L., Neftel, A.; Jocher, M., Ammann, C., Leifeld, J., Fuhrer, J., Calanca, P., Thalman, E., Pilegaard, K., Di Marco, C., Campbell, C., Nemitz, E., Hargreaves, K. J., Levy, P. E., Ball, B. C., Jones, S. K., van de Bulk, W. C. M., Groot, T., Blom, M., Domingues, R., Kasper, G., Allard, V., Ceschia, E., Cellier, P., Laville, P., Henault, C., Bizouard, F., Abdalla, M., Williams, M., Baronti, S., Berretti, F., and Grosz, B.: Effects of climate and management intensity on nitrous oxide emissions in grassland systems across Europe, Agr. Ecosyst. Environ., 121, 135-152, 2007.

Flechard, C. R., Nemitz, E., Smith, R. I., Fowler, D., Vermeulen, A. T., Bleeker, A., Erisman, J. W., Simpson, D., Zhang, L., Tang, Y. S., and Sutton, M. A.: Dry deposition of reactive nitrogen to European ecosystems: a comparison of inferential models across the NitroEurope network, Atmos. Chem. Phys., 11, 2703-2728, doi:10.5194/acp-11-2703-2011, 2011.

Flindt, R.: Biologie in Zahlen: Eine Datensammlung inTabellen mit ueber 10000 Einzelwerten, Spektrum akademischerVerlag, Gustav Fischer, 249 pp., 2002.

Galloway, J. N. and Cowling, E. B.: Reactive Nitrogen and the World: 200 Years of Change, Ambio, Optimizing Nitrogen Management in Food and EnergyProductions, and Environmental Change, 31, 64-71, 2002.

Gifford, R. M. and Roderick, M. L.: Soil carbon stocks and bulk density: spatial or cumulative mass coordinates as a basis of expression, Glob. Change Biol., 9, 1507-1514, 2003.

Gilmanov, T. G., Aires, L., Barcza, Z., Baron, V. S., Belelli, L., Beringer, J., Billesbach, D., Bonal, D., Bradford, J., Ceschia, E., Cook, D., Corradi, C., Frank, A., Gianelle, D., Gimeno, C., Gruenwald, T., Guo, H.Q., Hanan, N., Haszpra, L., Heilman, J., Jacobs, A., Jones, M. B., Johnson, D. A., Kiely, G., Li,S. G., Magliulo, V., Moors, E., Nagy, Z., Nasyrov, M., Owensby, C., Pinter, K., Pio, C., Reichstein, M., Sanz, M. J., Scott, R., Soussana, J. F., Stoy, P. C., Svejcar, T., Tuba, Z., and Zhou, G. S.: Partitioning European grassland net ecosystem $\mathrm{CO}_{2}$ exchange into gross primary productivity and ecosystem respiration using light response function analysis, Agr. Ecosyst. Environ., 121, 93-120, 2007.

Goidts, E. and Van Wesemael, B.: Regional assessment of soil organic carbon changes under agriculture in Southern Belgium (1955-2005), Geoderma, 141, 341-354, 2007.
Goidts, E., Van Wesemael, B., and Crucifix, M.: Magnitude and sources of uncertainties in soil organic carbon (SOC) stock assessments at various scales, Eur. J. Soil Sci., 60, 723-739, 2009.

Groffman, P. M., Altabet, M. A., Bohlke, J. K., Butterbach-Bahl, K., David, M. B., Firestone, M. K., Giblin, A. E., Kana, T. M., Nielsen, L. P., and Voytek, M. A.: Methods for measuring denitrification: Diverse approaches to a difficult problem, Ecol. Appl., 16, 2091-2122, 2006.

Haas, E., Klatt, S., Frohlich, A., Kraft, P., Werner, C., Kiese, R., Grote, R., Breuer, L., and Butterbach-Bahl, K.: LandscapeDNDC: a process model for simulation of biosphere-atmospherehydrosphere exchange processes at site and regional scale, Landscape Ecol., 28, 615-636, doi:10.1007/s10980-012-9772-x, 2013.

Hopkins, D. W., Waite, I. S., McNicol, J. W., Poulton, P. R., Macdonald, A. J., and O'Donnell, A. G.: Soil organic carbon contents in long-term experimental grassland plots in the UK (Palace Leas and Park Grass) have not changed consistently in recent decades, Glob. Change Biol., 15, 1739-1754, 2009.

IPCC: Climate change 1995, Impacts, adaptation and mitigation of climate change: scientic, technical analysis, contribution of working group II to the 2nd assessment reports of the IPCC 1996, Intergovernmental Panel on Climate Change and Cambridge University Press Cambridge UK, 1996.

IPCC: Guidelines for National Greenhouse Gas Inventories, Agriculture, Forestry and Other Land Use, Chapter 10: Emissions from Livestock and Manure Management, Intergovernmental Panel on Climate Change (IPCC), Institute for Global Environmental Strategies, Tokyo, Japan, 4, 2006a.

IPCC: Guidelines for National Greenhouse Gas Inventories, Agriculture, Forestry and Other Land Use, Chapter 11: $\mathrm{N}_{2} \mathrm{O}$ Emissions from Managed Soils, and $\mathrm{CO}_{2}$ Emissions from Lime and Urea Application, Intergovernmental Panel on Climate Change (IPCC) 2013, Institute for Global Environmental Strategies, Tokyo, Japan, 4, 2006b.

Janssens, I. A., Freibauer, A., Ciais, P., Smith, P., Nabuurs, G. J., Folberth, G., Schlamadinger, B., Hutjes, R. W. A., Ceulemans, R., Schulze, E. D., Valentini, R., and Dolman, A.J.: Europe's terrestrial biosphere absorbs 7 to $12 \%$ of European anthropogenic $\mathrm{CO}_{2}$ emissions, Science, 300, 1538-1542, 2003.

Jones, S. K., Rees, R. M., Kosmas, D., Ball, B. C., and Skiba, U. M.: Carbon sequestration in a temperate grassland; management and climatic controls, Soil Use Manage., 22, 132-142, 2006.

Jones, S. K., Rees, R. M., Skiba, U. M., and Ball, B. C.: Influence of organic and mineral $\mathrm{N}$ fertiliser on $\mathrm{N}_{2} \mathrm{O}$ fluxes from a temperate grassland, Agr. Ecosyst. Environ., 121, 74-83, 2007.

Jones, S. K., Famulari, D., Di Marco, C. F., Nemitz, E., Skiba, U. M., Rees, R. M., and Sutton, M. A.: Nitrous oxide emissions from managed grassland: a comparison of eddy covariance and static chamber measurements, Atmos. Meas. Tech., 4, 21792194, doi:10.5194/amt-4-2179-2011, 2011.

Jones, S. K., Helfter, C., Anderson, M., Coyle, M., Campbell, C., Famulari, D., Di Marco, C., van Dijk, N., Tang, Y. S., Topp, C. F. E., Kiese, R., Kindler, R., Siemens, J., Schrumpf, M., Kaiser, K., Nemitz, E., Levy, P. E., Rees, R. M., Sutton, M. A., and Skiba, U. M.: Carbon and nitrogen flux, meteorological, management and soil data from a grazed, cut and fertilised temperate grassland in south east Scotland, NERC Environmental In- 
formation Data Centre, doi:10.5285/7e6e6955-a9d7-4f8a-961e3fa3d56d0ead, 2017.

Kim, J., Verma, S. B., and Clement, R. J.: Carbon-Dioxide Budget in A Temperate Grassland Ecosystem, J. Geophys. Res-Atmos., 97, 6057-6063, 1992.

Kindler, R., Siemens, J., Kaiser, K., Walmsley, D. C., Bernhofer, C., Buchmann, N.,Cellier, P., Eugster, W., Gleixner, G., Grunwald, T., Heim, A., Ibrom, A., Jones, S. K., Jones, M., Klumpp, K., Kutsch, W., Larsen, K. S., Lehuger, S., Loubet, B., McKenzie, R., Moors, E., Osborne, B., Pilegaard, K., Rebmann, C., Saunders, M., Schmidt, M. W. I., Schrumpf, M., Seyfferth, J., Skiba, U., Soussana, J. F., Sutton, M.A., Tefs, C., Vowinckel, B., Zeeman, M. J., and Kaupenjohann, M.: Dissolved carbon leaching from soil is a crucial component of the net ecosystem carbon balance, Glob. Change Biol., 17, 1167-1185, 2011.

Kramberger, M., Podvršnik, A., Gselman, V., Šuštar, J., Kristl, M., Muršec, M., Lešnik, D., Škorjanc: The effects of cutting frequencies at equal fertiliser rates on bio-diverse permanent grassland: Soil organic $\mathrm{C}$ and apparent $\mathrm{N}$ budget, Agr. Ecosyst. Environ., 212, 13-20B, 2015.

Lambe, N. R., Navajas, E. A, McLean, K. A., Simm, G., and Bünger, L.: Changes in carcass traits during growth in lambs of two contrasting breeds, measured using computer tomography, Livest. Sci., 107, 37-52, 2007.

Leahy, P., Kiely, G., and Scanlon, T. M.: Managed grasslands: A greenhouse gas sink or source?, Geophys. Res. Lett., 31, L20507, 2004.

Leip A., Achermann, B., Billen, G., Bleeker, A., Bouwman, L., de Vries, W., Dragosits, U., Döring, U., Fernall, D., Geupel, M., Johnes, P., Le Gall, A.C., Monni, S., Neverčeřal, R., Orlandini, L., Prud'homme, M., Reuter, H., Simpson, D., Seufert, G., Spranger, T., Sutton, M. A., van Ardenne, J., Voss, M., and Winiwarter, W.: Integrating nitrogen fluxes at the European scale, Chapter 16 in: The European Nitrogen Assessment, edited by: Sutton, M. A., Howard, C. M., Erisman, J. W., Billen, G., Bleeker, A., Grennfelt, P., van Grinsven, H., and Grizzetti, B., 345-376, Cambridge University Press, 2011.

Lettens, S., Van Orshoven, J, Van Wesemael, B., De Vos, B., and Muys, B.: Stocks and fluxes of soil organic carbon for landscape units in Belgium derived from heterogeneous data sets for 1990 and 2000, Geoderma, 127, 11-23, 2005a.

Lettens, S., Van Orshoven, J., Van Wesemael, B., Muys, B., and Perrin, D.: Soil organic carbon changes in landscape units of Belgium between 1960 and 2000 with reference to 1990, Glob. Change Biol., 11, 2128-2140, 2005 b.

Luo, J., Tillman, R. W., and Ball, P. R.: Grazing effects on denitrification in a soil under pasture during two contrasting seasons, Soil. Biol. Biochem, 31, 903-912, 1999.

Marchand, R. F.: Ueber die chemische Zusammensetzung der Knochen, J. Prakt. Chem., 27, 83-97, doi:10.1002/prac.18420270117, 1842.

McKenzie, R. M., Özel, M. Z., Cape, J. N., Drewer, J., Dinsmore, K. J., Nemitz, E., Tang, Y. S., van Dijk, N., Anderson, M., Hamilton, J. F., Sutton, M. A., Gallagher, M. W., and Skiba, U.: The import and export of organic nitrogen species at a Scottish ombrotrophic peatland, Biogeosciences, 13, 2353-2365, doi:10.5194/bg-132353-2016, 2016.

McTiernan, K. B., Jarvis, S. C., Scholefield, D., and Hayes, M. H. B.: Dissolved organic carbon losses from grazed grasslands un- der different management regimes, Water Res., 35, 2565-2569, 2001.

Molina-Herrera S., Haas, E., Klatt, S., Kraus, D., Augustin, J., Magliulo, V., Tallec, T., Ceschia, E., Ammann C., Loubet, B., Skiba, U., Jones, S., Brümmer, C., Butterbach-Bahl, K., and Kiese, R.: A modelling study on mitigation of $\mathrm{N}_{2} \mathrm{O}$ emissions and $\mathrm{NO}_{3}$ leaching at different agricultural sites across Europe using LandscapeDNDC, Sci. Total Environ., 553, 128-140, 2016.

$\mathrm{Mu}$, Z., Huang, A., Ni, J., and Xie, D.: Linking annual $\mathrm{N}_{2} \mathrm{O}$ emission in organic soils to mineral nitrogen input as estimated by heterotrophic respiration and soil $\mathrm{C} / \mathrm{N}$ ratio, PLoS ONE 9, e96572, doi:10.1371/journal.pone.0096572, 2014.

Mudge, P. L., Wallace, D. F., Rutledge, S., Campbell, D. I., Schipper, L. A., and Hosking, C. L.: Carbon balance of an intensively grazed temperate pasture in two climatically contrasting years, Agr. Ecosyst. Environ., 144, 271-280, 2011.

Myhre, G., Shindell, D., Bréon, F.-M., Collins, W., Fuglestvedt, J., Huang, J., Koch, D., Lamarque, J.-F., Lee, D., Mendoza, B., Nakajima, T., Robock, A., Stephens, G., Takemura, T., andZhang, H.: Anthropogenic and Natural Radiative Forcing, in: Climate Change 2013: The Physical Science Basis, Contribution of Working Group I to the Fifth Assessment Report of the intergovernmental Panel on Climate Change, edited by: Stocker, T. F., Qin, D., Plattner, G.-K., Tignor, M., Allen, S. K., Boschung, J., Nauels, A., Xia, Y., Bex, V., and Midgley, P. M., Cambridge University Press, Cambridge, United Kingdom and New York, NY, USA, 2013.

Navajas, E. A., Richardson, R. I., Fisher, A. V., Hyslop, J. J., Ross, D. W., Prieto, N., Simm, G., and Roehe, R.: Predicting beef carcass composition using tissue weights of a primal cut assessed by computed tomography, Animal, 4, 1810-1817, doi:10.1017/S1751731110001096, 2010.

Neeteson, J. J. and Hassink, J.: Nitrogen Budgets of Three Experimental and Two Commercial Dairy Farms in the Netherlands, in: Perspectives for Agronomy, edited by: van Ittersum, M. K. and van de Geijn, S. C., Adopting ecological prinicples and managing resource use. Elsevier Science BV, Amsterdam, Developments in Crop Science, 25, 171-178, 1997.

Phoenix, G. K., Hicks, W.K., Cinderby, S., Kuylenstierna, J.C.I., Stock, W. D., Dentener, F. J., Giller, K. E., Austin, A. T., Lefroy, R. D. B., Gimeno, B. S., Ashmore, M. R., and Ineson, P.: Atmospheric nitrogen deposition in world biodiversity hotspots: the need for a greater global perspective in assessing $\mathrm{N}$ deposition impacts, Glob. Change Biol., 12, 470-476, 2006.

Powlson, D. S., Whitmore, A. P., and Goulding, K. W. T.: Soil carbon sequestration to mitigate climate change: A critical reexamination to identify the true and the false, Eur. J. Soil Sci., 62, 42-55, 2011.

Prescher, A. K., Grunwald, T., and Bernhofer, C.: Land use regulates carbon budgets in eastern Germany: From NEE to NBP, Agr. Forest Meteorol., 150, 1016-1025, 2010.

Rees, R. M., Bingham, I. J., Baddeley, J. A., and Watson, C.A.: The role of plants and land management in sequestering soil carbon in temperate arable and grassland ecosystems, Geoderma, 128, 130-54, 2005.

Reichstein, M., Falge, E., Baldocchi, D., Papale, D., Aubinet, M., Berbigier, P., Bernhofer, C., Buchmann, N., Gilmanov, T., Granier, A., Grunwald, T., Havrankova, K., Ilvesniemi, H., Janous, D., Knohl, A., Laurila, T., Lohila, A., Loustau, D., Mat- 
teucci, G., Meyers, T., Miglietta, F., Ourcival, J. M., Pumpanen, J., Rambal, S., Rotenberg, E., Sanz, M., Tenhunen, J., Seufert, G., Vaccari, F., Vesala, T., Yakir, D., and Valentini, R.: On the separation of net ecosystem exchange into assimilation and ecosystem respiration: review and improved algorithm, Glob. Change Biol., 11, 1424-1439, 2005.

Roche J.: The International Wool Trade, Woodhead Publishing, 1995.

Rudaz, A. O., Walti, E., Kyburz, G., Lehmann, P., and Fuhrer, J.: Temporal variation in $\mathrm{N}_{2} \mathrm{O}$ and $\mathrm{N}-2$ fluxes from a permanent pasture in Switzerland in relation to management, soil water content and soil temperature, Agr. Ecosyst. Environ., 73, 83-91, 1999.

Ryden, J. C., Ball, P. R., and Garwood, E. A.: Nitrate Leaching from Grassland, Nature, 311, 50-53, 1984a.

Ryden, J. C. and McNeill, J. E.: Application of the micrometeorological mass balance method to the determination of ammonia loss from a grazed sward, J. Sci. Food Agric., 35, 1297-1310, 1984.

Rytter, R. M., Rytter, L., and Hogbom, L.: Carbon sequestration in willow (Salix spp.) plantations on former arable land estimated by repeated field sampling and $\mathrm{C}$ budget calculation, Biomass Bioenerg., 83, 483-492, 2015.

Schipper, L. A., Baisden, W. T., Parfitt, R. L., Ross, C., Claydon, J. J., and Arnold, G.: Large losses of soil $\mathrm{C}$ and $\mathrm{N}$ from soil profiles under pasture in New Zealand during the past 20 years, Glob. Change Biol, 13, 1138-1144, 2007.

Scholefield, D., Tyson, K. C., Garwood, E. A., Armstrong, A. C., Hawkins, J., and Stone, A. C.: Nitrate Leaching from Grazed Grassland Lysimeters - Effects of Fertilizer Input, Field Drainage, Age of Sward and Patterns of Weather, J. Soil Sci., 44, 601-613, 1993.

Schuman, G. E., Janzen, H. H., and Herrick, J. E.: Soil carbon dynamics and potential carbon sequestration by rangelands, Environ. Pollut., 116, 391-396, 2002.

Schulze, E.D ., Luyssaert, S., Ciais, P., Freibauer, A., Jannsens, I. A., Soussana, J. F., Grace, J., Levin, I., Thiruchittampalam, B., Heimann, M., Dolman, A. J., Valentini, R., Bousquet, P., Peylin, P., Peters, W., Rödenbeck, C., Etiope, G., Vuichard, N., Wattenbach, M., Nabuurs, G. J., Poussi, Z., Nieschulze, J., and Gach, J. H.: Importance of methane and nitrous oxide for Europe's terrestrial greenhouse-gas balance, Nat. Geosci., 2, 842-850, 2009.

Scottish Agricultural College: Farm management handbook SAC, edited by: Chadwick, L., Edinburgh, 1995.

Scottish Agricultural College: Technical Note TN652: Fertiliser recommendations for grasslands, edited by: Sinclair, A., Shipway, P. A., and Crooks, B., 2013.

Siemens, J.: The European carbon budget: A gap, Science, 302, 1681, doi:10.1126/science.302.5651.1681a, 2003.

Skiba, U., Drewer, J., Tang, Y. S., van Dijk, N., Helfter, C., Nemitz, E., Famulari, D., Cape, J. N., Jones, S. K., Twigg, M., Pihlatie, M., Vesala, T., Larsen, K. S., Carter, M. S., Ambus, P., Ibrom, A., Beier, C., Hensen, A., Frumau, A., Erisman, J. W., Brüggemann, N., Gasche, R., Butterbach-Bahl, K., Neftel, A., Spirig, C., Horvath, L., Freibauer, A., Cellier, P., Laville, P., Loubet , B., Magliulo, E., Bertolini, T., Seufert, G., Andersson, M., Manca, G., Laurila, T., Aurela, M., Lohila A., Zechmeister-Boltenstern, S., Kitzler, B., Schaufler, G., Siemens, J., Kindler, R., Flechard, C., and Sutton, M. A.: Biosphere atmosphere exchange of reactive nitrogen and greenhouse gases at the NitroEurope core flux measurement sites: Measurement strategy and first annual data set, Agr. Ecosys. Environ., 133, 139-149, 2009.

Skiba, U., Drewer, J., Tang, Y., van Dijk, N., Helfter, C., Nemitz, E., Famulari, D., Cape, J., Jones, S., and Twigg, M.:. Biosphereatmosphere exchange of reactive nitrogen and greenhouse gases at the NitroEurope core flux measurement sites: Measurement strategy and first data sets, Agr. Ecosyst. Environ., 133, 139-149, doi:10.1016/j.agee.2009.05.018, 2009.

Skiba, U., Jones, S. K., Drewer, J., Helfter, C., Anderson, M., Dinsmore, K., McKenzie, R., Nemitz, E., and Sutton, M. A.: Comparison of soil greenhouse gas fluxes from extensive and intensive grazing in a temperate maritime climate, Biogeosciences, 10, 1231-1241, doi:10.5194/bg-10-1231-2013, 2013.

Smith, P. : How long before a change in soil organic carbon can be detected?, Glob. Change Biol., 10, 1878-83, 2004

Smith, P., Haberl, H., Popp, A., Erb, K.-H., Lauk, C., Harper, R., Tubiello, F. N., de Siqueira Pinto, A., Jafari, M., Sohi, S., Masera, O., Böttcher, H., Berndes, G., Bustamante, M., Ahammad, H., Clark, H., Dong, H., Elsiddig, E. A., Mbow, C., Ravindranath, N. H., Rice, C. W., Robledo Abad, C., Romanovskaya, A., Sperling, F., Herrero, M., House, J. I., and Rose, S.: How much land based greenhouse gas mitigation can be achieved without compromising food security and environmental goals?, Glob. Change Biol., 19, 2285-2302, 2013.

Smith, P.: Do grasslands act as a perpetual sink for carbon?, Glob. Change Biol., 20, 2708-2711, 2014.

Soussana, J. F., Loiseau, P., Vuichard, N., Ceschia, E., Balesdent, J., Chevallier, T., and Arrouays, D.: Carbon cycling and sequestration opportunities in temperate grasslands, Soil Use Manage., 20, 219-230, 2004.

Soussana, J. F., Allard, V, Pilegaard, K., Ambus, P., Amman, C., Campbell, C., Ceschia, E., Clifton-Brown, J., Czobel, S., Domingues, R., Flechard, C., Fuhrer, J., Hensen, A., Horvath, L., Jones, M., Kasper, G., Martin, C., Nagy, Z., Neftel, A., Raschi, A., Baronti, S., Rees, R. M., Skiba, U., Stefani, P., Manca, G., Sutton, M., Tubaf, Z., and Valentini, R.: Full accounting of the greenhouse gas $\left(\mathrm{CO}_{2}, \mathrm{~N}_{2} \mathrm{O}, \mathrm{CH}_{4}\right)$ budget of nine European grassland sites, Agr. Ecosyst. Environ., 121, 121-134, 2007.

Soussana, J. F., Tallec, T., and Blanfort, V.: Mitigating the greenhouse gas balance of ruminant production systems through carbon sequestration in grasslands, Animal, 4, 334-350, 2010.

Soussana, J. F. and Lemaire, G.: Coupling carbon and nitrogen cycles for environmentally sustainable intensification of grasslands and crop-livestock systems, Agr. Ecosyst. Environ., 190, 9-17, 2014.

Stewart, A. A., Little, S. M., Ominski, K.H., Wittenberg, K. M., and Janzen, H. H.: Evaluating greenhouse gas mitigation practices in livestock systems: an illustration of a whole-farm approach, J. Agr. Jci., 147, 367-382, 2009.

Sutton, M. A., Tang, Y. S., Miners, B., and Fowler, D.: A New Diffusion Denuder System for Long-Term, Regional Monitoring of Atmospheric Ammonia and Ammonium, Water Air Soil Poll., 1, 145-56, 2001.

Sutton, M. A., Nemitz, E., Erisman, J. W., Beier, C., ButterbachBahl, K., Cellier, P., de Vries, W., Cotrufo, F., Skiba, U., Di Marco, C., Jones, S., Laville, P., Soussana, J. F., Loubet, B., Twigg, M., Famulari, D., Whitehead, J., Gallagher, M. W., Neftel, A., Flechard, C. R., Herrmann, B., Calanca, P. L., Schjoerring, J. K., Daemmgen, U., Horvath, L., Tang, Y. S., Emmett, B. 
A., Tietema, A., Pe nuelas, J., Kesik, M., Brueggemann, N., Pilegaard, K., Vesala, T., Campbell, C. L., Olesen, J. E., Dragosits, U., Theobald, M. R., Levy, P., Mobbs, D. C., Milne, R., Viovy, N., Vuichard, N., Smith, J. U., Smith, P., Bergamaschi, P., Fowler, D., and Reis, S.: Challenges in quantifying biosphereatmosphere exchange of nitrogen species, Environ. Pollut., 150, 125-139, 2007.

Sutton, M. A., Oenema, O., Erisman, J. W., Leip, A., van Grinsven, H., and Winiwarten, W.: Too much of a good thing, Nature 472, 159-161, doi:10.1038/472159a, 2011.

Tyson, K. C., Garwood, E. A., Armstrong, A.C., and Scholefield, D.: Effects of Field Drainage on the Growth of Herbage and the Liveweight Gain of Grazing Beef-Cattle, Grass Forage Sci., 47, 290-301, 1992.

Twigg, M. M., House, E., Thomas, R., Whitehead, J., Phillips, G. J., Famulari, D., Fowler, D., Gallagher, M. W., Cape, J. N., Sutton, M. A.,and Nemitz, E.: Surface/atmosphere exchange and chemical interactions of reactive nitrogen compounds above a manured grassland, Agr. Forest Meteorol., 151, 1488-1503, 2011.

Van der Hoek, K. W.: Nitrogen efficiency in global animal production, Environ. Pollut., 102, 127-132, 1998.
Van der Salm, C., Dolfing, J., Heinen, M., and Velthof, G. L.: Estimation of nitrogen losses via denitrification from a heavy clay soil under grass, Agr. Ecosyst. Environ., 119, 311-319, 2007.

Velthof, G. L. and Oenema, O.: Nitrous oxide fluxes from grassland in the Netherlands, Effects of soil type, nitrogen fertilizer application and grazing, Eur. J. Soil Sci., 46, 541-549, 1995.

Watson, C. J., Jordan, C., Kilpatrick, D., McCarney, B., and Stewart, R.: Impact of grazed grassland management on total $\mathrm{N}$ accumulation in soil receiving different levels of $\mathrm{N}$ inputs, Soil Use Manage., 23, 121-128, 2007.

Wendt, J.W. and Hauser, S.: An equivalent soil mass procedure for monitoring soil organic carbon in multiple soil layers, Eur. J. Soil Sci., 64, 58-65, 2013.

Whitehead, D. C., Pain, B. F., and Ryden J. C.: Nitrogen in UK grassland agriculture, J. R. Agric. Soc., 147, 190-201, 1986.

Zhang, Y., Xu, M., Chen, H. ,and Adams, J.: Global Pattern of NPP to GPP Ratio Derived from MODIS Data: Effects of Ecosystem Type, Geographical Location and Climate, Glob. Ecol. Biogeogr., 18, 280-90, doi:10.1111/j.1466-8238.2008.00442.x, 2009 . 